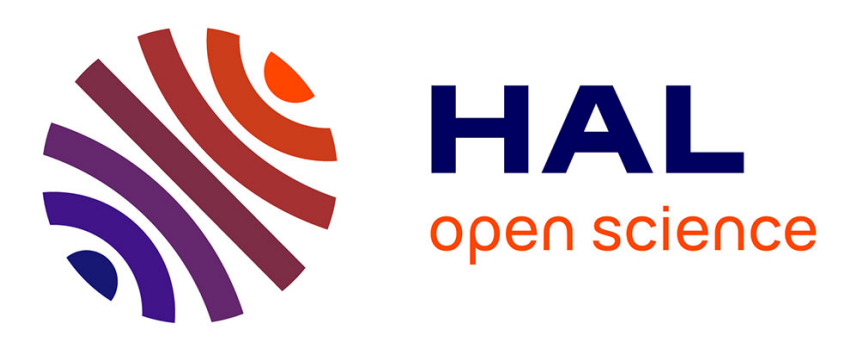

\title{
Electrochemical Study of the Versatility of a Solid Cell Working both as Fuel Cell and Electrolysis Modes
}

\author{
E. Pichot, M. Olivon, A. Perraud, O. Joubert, A. Le Gal La Salle
}

\section{To cite this version:}

E. Pichot, M. Olivon, A. Perraud, O. Joubert, A. Le Gal La Salle. Electrochemical Study of the Versatility of a Solid Cell Working both as Fuel Cell and Electrolysis Modes. Fuel Cells, 2020, 8th Fundamentals \& Development of Fuel Cells Conference FDFC2019, 20 (3), pp.332-341. 10.1002/fuce.201900066 . hal-02649125

\section{HAL Id: hal-02649125 \\ https://hal.science/hal-02649125}

Submitted on 25 Nov 2020

HAL is a multi-disciplinary open access archive for the deposit and dissemination of scientific research documents, whether they are published or not. The documents may come from teaching and research institutions in France or abroad, or from public or private research centers.
L'archive ouverte pluridisciplinaire HAL, est destinée au dépôt et à la diffusion de documents scientifiques de niveau recherche, publiés ou non, émanant des établissements d'enseignement et de recherche français ou étrangers, des laboratoires publics ou privés. 


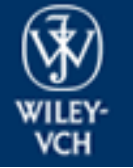

Fuel Cells

\section{Electrochemical study of the versatility of a solid cell working both as fuel cell and electrolysis modes}

\begin{tabular}{|c|c|}
\hline Journal: & Fuel Cells \\
\hline Manuscript ID & fuce.201900066.R1 \\
\hline Wiley - Manuscript type: & Original Research Paper \\
\hline $\begin{array}{r}\text { Date Submitted by the } \\
\text { Author: }\end{array}$ & $n / a$ \\
\hline Complete List of Authors: & $\begin{array}{l}\text { Le Gal La Salle, Annie; Centre National de la Recherche Scientifique } \\
\text { Pichot, Erwan; Centre National de la Recherche Scientifique } \\
\text { Olivon, Maxime; Centre National de la Recherche Scientifique } \\
\text { Perraud, Alexandre; Centre National de la Recherche Scientifique } \\
\text { Joubert, Olivier }\end{array}$ \\
\hline Keywords: & $\begin{array}{l}\text { Electrochemical Impedance Spectroscopy, Solid Oxide Fuel Cell, Solid } \\
\text { Oxide Electrolysis Cell, Ni-YSZ, LSCF }\end{array}$ \\
\hline
\end{tabular}

\section{SCHOLARONE ${ }^{\text {W }}$ \\ Manuscripts}




\title{
Electrochemical study of the versatility of a solid cell working
}

\section{both as fuel cell and electrolysis modes}

\author{
E. Pichot ${ }^{1}$, M. Olivon ${ }^{1}$, A. Perraud ${ }^{1}$, O. Joubert ${ }^{1}$ and A. Le Gal La Salle ${ }^{1, *}$ \\ ${ }^{1}$ Institut des Matériaux Jean Rouxel (IMN), CNRS-Université de Nantes UMR6502, 2 rue de \\ la Houssinière, BP 32229, 44322 Nantes Cedex 3, France
}

[*]Corresponding author: annie.legal@cnrs-imn.fr

\begin{abstract}
A Ni/Yttria-stabilized zirconia (YSZ) cell with a $\left(\mathrm{La}_{0.60} \mathrm{Sr}_{0.40}\right)_{0.95} \mathrm{Co}_{0.20} \mathrm{Fe}_{0.80} \mathrm{O}_{3-\delta}$ cathode is tested both in fuel cell and electrolysis modes. In fuel cell mode under dry air and wet $\mathrm{H}_{2}$, the cell is operated between the Open Circuit Voltage and $0.4 \mathrm{~V}$ and reaches $330 \mathrm{~mW} \mathrm{~cm}^{-2}$ at $850^{\circ} \mathrm{C}$ for $157 \mathrm{~mL} \mathrm{~min}{ }^{-1} \mathrm{H}_{2}$ supply. The influence of temperature and air or hydrogen flow rate is studied, and impedance measurements show that below $0.8 \mathrm{~V}$ the electrolyte becomes the more resistive part of the cell. Nevertheless, fuel utilization yields are higher under oxygen or hydrogen depletion. If it is possible at $750^{\circ} \mathrm{C}$ to work at low voltage during several hours in the entire voltage range, the voltage decrease must be limited at $850^{\circ} \mathrm{C}$. The cell can also be operated under wet air. The same cell can be operated in electrolysis mode, and a power density of $340 \mathrm{~mW} \mathrm{~cm}^{-2}$ can obtained at $0.3 \mathrm{~V} / \mathrm{OCV}$ under $100 \mathrm{~mL} \mathrm{~min}^{-1}$ wet $\left(3 \% \mathrm{H}_{2} \mathrm{O}\right)$ $5 \% \mathrm{H}_{2}-95 \%$ Ar mixture on the fuel side and dry or wet $100 \mathrm{~mL} \mathrm{~min}^{-1}$ air flow on the air side. Nevertheless, bubbling air providing the air electrode in salt water has an irreversible detrimental effect on the cell.

Keywords: Solid Oxide Fuel Cell, Solid Oxide Electrolysis Cell, Electrochemical Impedance spectroscopy, Ni-YSZ, LSCF.
\end{abstract}




\section{Introduction}

Energy transition involves the use of a mix of renewable energy resources. Nevertheless, these resources are intermittent, and storage technologies must be developed in order to balance the energy supply and demand. Hydrogen, which can be produced from electrolysis of water using renewable energy, and can also be converted in electricity without noxious gases by a fuel cell, seems a promising energy carrier [1,2]. Solid oxide fuel cells (SOFCs), working at high temperatures, are of great interest due to their high energy efficiency and their robustness, even when they are fuel with gaseous mixtures of carbon-containing components [3-5]. The reverse of SOFCs, i.e. solid oxide electrolyzer cells (SOECs), has gained much attention lately due to its advantages over low-temperature electrolysis for its excellent efficiency in hydrogen production [6-8], and possibility of co-electrolysis of $\mathrm{H}_{2} \mathrm{O}$ with $\mathrm{CO}_{2}$ [9-11].Some publications report also the possible electrolysis of seawater, which is a worldwide spread and low-cost resource [12-14].

Moreover, in order to still lower production costs [15], it is also interesting to have the same cell operating both in electrolysis and in fuel cell modes. Such cells have been reported, but their long-term stability seems to be strongly dependent on operation conditions, whose study must be continued [16-18]. Among the different air-electrode compounds, $\mathrm{La}_{1-\mathrm{x}} \mathrm{Sr}_{\mathrm{x}} \mathrm{Co}_{1-\mathrm{y}} \mathrm{Fe}_{\mathrm{y}} \mathrm{O}_{3-}$ ${ }_{\delta}$ (LSCF) perovskites remain widely studied in fuel cell mode, but also as cathode materials for SOEC [19-25]. Even if the degradation of nickel/yttria-stabilized zirconia cermet, which is commonly used as fuel electrode material, has also been reported [26,27], it seems also that its long-term stability can be increased by reversibly cycling between electrolysis and fuelcell modes $[16,20,28]$. Nevertheless conflicting results require further studies realized under different operation conditions. This paper presents therefore a systematic study, based on electrochemical impedance spectroscopy, of the operation, both in electrolysis and fuel-cell modes, and performed at different voltages or under different gases supply conditions, of a complete solid oxide electrochemical cell associating LSCF as the air electrode and Ni/YSZ 
as the fuel electrode. In the aim of coupling such system with renewables marine energies in harbor facilities, prospective studies under marine atmosphere are also carried out.

\section{Experimental}

\subsection{Cells}

SOFC unit cells are commercial $(5 \mathrm{~cm}$ or 2.5 diameter) circular shaped planar anodesupported 2R-Cell ${ }^{\mathrm{TM}}$ from the swiss company Fiaxell schematized in Figure $1[29,30]$. They are composed of materials commonly entering SOFC composition, i.e. an optimized Ni/Yttria-stabilized zirconia (YSZ) anode [31,32], an YSZ electrolyte covered by a gadolinium-doped ceria layer GDC [33] containing a small amount of cobalt oxide as sintering aid, and $\mathrm{a}\left(\mathrm{La}_{0.60} \mathrm{Sr}_{0.40}\right)_{0.95} \mathrm{Co}_{0.20} \mathrm{Fe}_{0.80} \mathrm{O}_{3-\delta}$ cathode.

\subsection{Cell testing setup}

The experimental open-flange setup (Figure 2) [29,30,34] provided by the swiss company Fiaxell is particularly suitable for versatile cells working alternatively in fuel cell and electrolyzer modes. It contains an oven and an inconel support in order to maintain the cell in the furnace. The current collection is provided by a nickel contact (a) on the fuel side and a gold grid (b) on the air side, connected to four wires. Three of them are used to collect the current (c) and the fourth one to read the cell potential (d). Two alumina felts (e) are placed on each collection grid avoid any current leakage. This cell assembly is firmly squeezed between the two inconel flanges (f) and (g) using spring loaded rods (h) inserted in the tubes (i) maintaining fuel and air flowing close to the electrodes, on each side of the cell (j). The cell temperature is measured by a K-type thermocouple inserted in a small inconel tube $(\mathrm{k})$ in contact to the upper alumina felt at the air side. At the fuel side, the $\mathrm{H}_{2}$-containing mixture, after bubbling in water at room temperature $\left(\mathrm{H}_{2} \mathrm{O}=0.3 \mathrm{~atm}\right)$, is fed (red arrows in the Figure 
2) to the cell through the tube on the bottom flange (1). The coherence between results obtained in previous studies [35-38] when $\mathrm{N}_{2}$ or Ar is used as diluting gas suggests that results do not depend on the nature of diluting gas, and in this study, argon was used as the diluting gas. Then, as water is produced or brought at the fuel electrode both in fuel cell or electrolysis modes, all experiments are realized with wet fuel mixtures. The air, provided by the laboratory network, after filtering and degreasing, under atmospheric pressure, comes by the top ( $\mathrm{m}$ and yellow arrows). In order to study the influence of humidity or saline humidity, some experiments were realized with air bubbling in water or salt water at room temperature $\left(p \mathrm{H}_{2} \mathrm{O}=0.3 \mathrm{~atm}\right)$. The excess of fuel burns with air at the edges of the cell, in the alumina felts.

The fuel cells are submitted to the following temperature program: ramp $120^{\circ} \mathrm{C} \mathrm{h}^{-1}$ until the temperature reaches $620^{\circ} \mathrm{C}$ at the thermocouple, under air. Then at the $620^{\circ} \mathrm{C}$ stage, $200 \mathrm{~mL}$ $\min ^{-1}$ of a $\operatorname{Ar} 95 \%-\mathrm{H}_{2} 5 \%$ mixture is provided during 15 hours. This step is necessary to activate the anode, i.e. induce the reduction of $\mathrm{NiO}$ to $\mathrm{Ni}$, and also remove trace amounts of pore-formers used in the anode preparation. The final measurement temperature is reached after a $120{ }^{\circ} \mathrm{C} \mathrm{h}^{-1}$ ramp at the same gas flow, and the cell is fueled with the chosen gas mixture.

\subsection{Polarization curves}

The current collectors, made of discs of gold grid connected to the air electrode and of nickel grid connected to the fuel electrode, are linked to the external current and voltage circuits for electrical measurements. Polarization curves are obtained by the Versastat device (Princeton Applied Research) and the associated software VersaStudio in linear square wave voltammetry mode at the $1 \mathrm{mV} \mathrm{s}^{-1}$ scan rate, provided by Ametek France. Power density versus current density curves are then deduced thanks to Ohm law. From the polarization curves the Area-Specific Resistance (ASR), expressed in $\Omega \mathrm{cm}^{2}$, can be 
calculated at Open Circuit Voltage (OCV) or at any point of the curve thanks to the slope of the curve around this point.

\subsection{Electrochemical impedance spectroscopy}

Electrochemical impedance spectroscopy was performed at the OCV using a Versastat device and the associated software VersaStudio, in potentiostatic EIS mode, start frequency $10,000 \mathrm{~Hz}$, end frequency $0.1 \mathrm{~Hz}$ and $20 \mathrm{mV}$ or $10 \mathrm{mV}$ as amplitude of the perturbation signal. This later value has been optimized for each measurement in order to get the best signal to noise ratio without any loss of the transfer function linearity $[39,40]$. The impedance data were analysed using ZView2-Software [41].

\section{Results and Discussion}

\subsection{Characterization of cells working on fuel cell mode under dry air}

\subsubsection{Influence of the temperature and of the voltage}

Figure 3A shows the voltage (a) and power density (b) versus current density characteristics of the cells recorded at $10 \mathrm{mV} \mathrm{s}^{-1}$ under wet $\left(3 \% \mathrm{H}_{2} \mathrm{O}\right) 69 \% \mathrm{H}_{2}-31 \%$ Ar mixture (i.e. corresponding to a $\mathrm{H}_{2}$ flow of $\left.157 \mathrm{~mL} \mathrm{~min}^{-1}\right)$ on the fuel side and dry air $\left(400 \mathrm{~mL} \mathrm{~min}^{-1}\right)$ on the air side, and at $850^{\circ} \mathrm{C}$. The same curves obtained in the same conditions but at $750^{\circ} \mathrm{C}$ are shown on curves (c) and (d). As expected from Nernst equation, the Open Circuit Voltage (OCV) is higher when the temperature is smaller, whereas the slope of the curve at the origin is higher, leading finally to a crossing of the curves. Consequently, the higher the temperature, the higher the maximal power density $\left(330 \mathrm{~mW} \mathrm{~cm}^{-2}\right.$ at $850^{\circ} \mathrm{C}$ and $175 \mathrm{~mW} \mathrm{~cm}^{-2}$ at $\left.750^{\circ} \mathrm{C}\right)$, as observed in $[20,22,35,37,42,43]$. As already observed in previous studies $[30,35,37,38]$, the use of redox-tolerant Fiaxell cells allows to decrease the voltage drastically, here at $0.4 \mathrm{~V}$. 
Curve a of Figure $3 \mathrm{~B}$ presents the impedance diagram obtained at $O C V$ and at $850{ }^{\circ} \mathrm{C}$ under wet $\left(3 \% \mathrm{H}_{2} \mathrm{O}\right) 69 \% \mathrm{H}_{2}-31 \%$ Ar mixture (i.e. corresponding to a $\mathrm{H}_{2}$ flow of $\left.157 \mathrm{~mL} \mathrm{~min}^{-1}\right)$ on the fuel side and air $\left(400 \mathrm{~mL} \mathrm{~min}^{-1}\right)$ on the air side. It presents two depressed semi-circles, and can be fitted by the electrical equivalent circuit $\mathrm{L}+\mathrm{R}_{1}+\left(\mathrm{R}_{2} / / \mathrm{CPE}_{2}\right)+\left(\mathrm{R}_{3} / / \mathrm{CPE}_{3}\right)[24,44]$. The impedance formula of the Constant Phase Elements CPE is $1 / \mathrm{Q}(\mathrm{j} \omega)^{\mathrm{n}}$, with an associated capacitance $C$ which can be calculated from the formula

$$
(\mathrm{RC})^{\mathrm{n}}=\mathrm{RQ}
$$

The inductance $\mathrm{L}$ is related to the wires and ranges between $0.510^{-6} \mathrm{H}$ and $1.010^{-6} \mathrm{H}$ for all measurements, in accordance with literature with a similar testing set-up [47]. The series resistance $\mathrm{R}_{1}$, related mainly to the GDC/YSZ electrolyte and the set-up ohmic resistance [33, 48] is of $0.39 \pm 0.05 \Omega \mathrm{cm}^{2}$. The thickness of the electrolyte, of about $20 \mu \mathrm{m}$, i.e. twice more than other Fiaxell cells integrating the same cathode material previously tested [49], is responsible for this rather high $\mathrm{R}_{1}$ value, but also for the rather low power density recorded with this cell and its drastic dependence on temperature.

The capacitance $\mathrm{C}_{2}$ and $\mathrm{C}_{3}$ are respectively of $1.810^{-4} \mathrm{~F} \mathrm{~cm}^{-2}$ and $0.510^{-1} \mathrm{~F} \mathrm{~cm}^{-2}$ whereas $\mathrm{R}_{2}$ and $\mathrm{R}_{3}$ are respectively of $1.18 \Omega \mathrm{cm}^{2}$ and $0.62 \Omega \mathrm{cm}^{2}$. If the complete interpretation is difficult [24], these results, in accordance with results obtained in similar conditions $[20,24,28]$, suggest that the corresponding resistances are mainly correlated to gas phase transport across electrode surfaces, such as diffusion and adsorption phenomena [50-60], even if a small contribution of charge transfer to $\mathrm{R}_{2}$ is not excluded. Adding the three resistances $\mathrm{R}_{1}, \mathrm{R}_{2}$ and $\mathrm{R}_{3}$ (i.e. corresponding to the intersection of the low frequency part of the diagram with the real axis) gives the total resistance $\mathrm{R}_{\mathrm{t}}$ of the cell, which corresponds also to the slope of the $\mathrm{U}$ versus $\mathrm{J}$ curve at origin, plotted as the dotted line in Figure 3. Indeed, at OCV, the electrolyte resistance $\mathrm{R}_{1}$ contributes to only $18.5 \%$ of the total resistance of the cell. Impedance diagrams were also plotted at $0.8 \mathrm{~V}, 0.6 \mathrm{~V}$ and $0.4 \mathrm{~V}$. They present the same shape as the diagram a, and can be fitted by the same electrical equivalent circuit, with 
corresponding resistance and capacitance values collected in Table 1. In accordance with the regular decrease of the slope of the U/J curve when the voltage decreases (curve a of Figure 3), $R_{t}$ decreases when the voltage decreases, with a minimum value at $0.6 V$. This $R_{t}$ decrease is mainly due to the decrease of $R_{2}$ (whereas $C_{2}$ remains nearly unchanged), suggesting that the corresponding mass transfer phenomena are less rate-limiting at these voltages. The decrease of $R_{3}$ contributes also to this $R_{t}$ decrease, but mainly between OCV and $0.8 \mathrm{~V}$. As the electrode resistance decreases when the voltage decreases, whereas the electrolyte resistance remain unchanged, the part of the resistance of the cell due to electrolyte increases regularly: $47,9 \%$ at $0.8 \mathrm{~V}, 55,6 \%$ at $0.6 \mathrm{~V}$ and $61,5 \%$ at $0.4 \mathrm{~V}$.

Curve $b$ of Figure 3B presents the impedance diagrams obtained in similar conditions but at $750^{\circ} \mathrm{C}$. The $\mathrm{R}_{1}$ value, of $3.27 \Omega \mathrm{cm}^{2}$, is higher than that measured at $850{ }^{\circ} \mathrm{C}$, in accordance with usually reported variations of YSZ conductivities with temperature, following an Arrhenius law [48]. $\mathrm{R}_{2}$ and $\mathrm{R}_{3}$ values increase drastically, reaching respectively $3.46 \Omega \mathrm{cm}^{2}$ and $6.16 \Omega \mathrm{cm}^{2}$ whereas the $C_{2}$ and $C_{3}$ decrease weakly, to $1.410^{-4} \mathrm{~F} \mathrm{~cm}^{-2}$ and $0.310^{-1} \mathrm{~F} \mathrm{~cm}^{-2}$. As a consequence, the total resistance of the cell, in accordance Figure 3 (curve b), is also higher. At $\mathrm{OCV}$, contribution of the electrodes to the total polarisation resistance represents $74.6 \%$ of the total resistance of the cell.

Impedance diagrams were also plotted at $0.8 \mathrm{~V}, 0.6 \mathrm{~V}$ and $0.4 \mathrm{~V}$. They present the same shape as the diagram a, and can be fitted by the same electrical equivalent circuit, with corresponding resistance and capacitance values collected in Table 1 . Whereas $\mathrm{C}_{2}$ and $\mathrm{C}_{3}$ remain unchanged, $R_{2}$ and $R_{3}$ decreases regularly when the voltage decreases, leading to a regular decrease of $\mathrm{R}_{\mathrm{t}}$. Consequently, the contribution of the electrolyte to the total resistance of the cell, which was only $25.4 \%$ at $\mathrm{OCV}$, increases regularly when the voltage decrease to become the most resistive part of the cell: $43.1 \%$ at $0.8 \mathrm{~V}, 52.4 \%$ at $0.6 \mathrm{~V}$ and $68.2 \%$ at $0.4 \mathrm{~V}$.

\subsubsection{Influence of the composition of the gases supplying the electrodes}


Figure 4A shows the voltage (a, b and c) and power density (a', b' and c' versus current density characteristics of the cells recorded at $10 \mathrm{mV} \mathrm{s}^{-1}$ and at $850{ }^{\circ} \mathrm{C}$ under dry air $(400 \mathrm{~mL}$ $\left.\min ^{-1}\right)$ on the air side and wet $\left(3 \% \mathrm{H}_{2} \mathrm{O}\right)$ mixtures of $60 \% \mathrm{H}_{2}-40 \%$ Ar mixture (i.e. corresponding to a $\mathrm{H}_{2}$ flow of $107 \mathrm{~mL} \mathrm{~min}^{-1}$ ) (curves a and a'), 53\% $\mathrm{H}_{2}-47 \%$ Ar mixture (i.e. corresponding to a $\mathrm{H}_{2}$ flow of $83 \mathrm{~mL} \mathrm{~min}^{-1}$ ) (curves b and b'), and $44 \% \mathrm{H}_{2}-56 \%$ Ar mixture (i.e. corresponding to a $\mathrm{H}_{2}$ flow of $57 \mathrm{~mL} \mathrm{~min}^{-1}$ ) (curves $\mathrm{c}$ and c') on the fuel side. If curve a, obtained for $107 \mathrm{~mL} \mathrm{~min}-1$ of $\mathrm{H}_{2}$, is nearly similar to curve a of Figure 3, a more important decrease of the $\mathrm{H}_{2}$ concentration leads to a decrease of the maximal power density (Table 2), in accordance with the modification of the U versus J curves. Nevertheless, for a decrease of the hydrogen flow from $157 \mathrm{~mL} \mathrm{~min}^{-1}$ to $57 \mathrm{~mL} \mathrm{~min}^{-1}$ (i.e. of $64 \%$ ) the power density decrease is only of $33 \%$, suggesting that the fuel cell utilization yield is in fact higher when the hydrogen flow is lower. Results obtained when modifying the air flow are presented on Figure 4B. When the oxygen flow decreases, the decrease of the voltage with current density is more important, leading to a more drastic decrease of the maximal power densities (Table 2): in these cases the oxygen supply is too low compared to the hydrogen one, and the oxygen reduction becomes the rate-limiting steps. Nevertheless, as in the case for hydrogen depletion, oxygen depletion leads to an increase of the fuel utilization yield.

Figure $4 \mathrm{C}$ presents the impedance diagrams obtained at $\mathrm{OCV}$ for different fueling conditions. Whereas diminishing the $\mathrm{O}_{2}$ concentration doesn't lead to change in the impedance diagram (curves $\mathrm{d}$, e and $\mathrm{f}$ ), the decrease of the $\mathrm{H}_{2}$ concentration leads to a continuous increase of the resistance $R_{3}$. As shown on Figure $4 \mathrm{D}$ and Table 3, when $\mathrm{R}_{3}$ increases, the corresponding relaxation frequency decreases, resulting in negligible change of capacitance. Impedance diagrams were plotted at $850^{\circ} \mathrm{C}$ for different fueling conditions at $0.8 \mathrm{~V}, 0.6 \mathrm{~V}$ and 0.4V. All diagrams have the same shape and can be fitted by the electrical equivalent circuit L $+\mathrm{R}_{1}+\left(\mathrm{R}_{2} / / \mathrm{CPE} \mathrm{E}_{2}\right)+\left(\mathrm{R}_{3} / / \mathrm{CPE}_{3}\right) . \mathrm{L}$ and $\mathrm{R}_{1}$ remain unchanged, respectively in the $0.510^{-6} \mathrm{H}-$ $1.010^{-6} \mathrm{H}$ and $0.39 \Omega \mathrm{cm}^{2}-0.42 \Omega \mathrm{cm}^{2}$ ranges. Values of $\mathrm{R}_{2}, \mathrm{C}_{2}, \mathrm{R}_{3}$ and $\mathrm{C}_{3}$ are collected in 
Table 3, and Figures 5A and 5B show the variations of the two resistances when the concentrations of $\mathrm{H}_{2}$ and $\mathrm{O}_{2}$ decrease. $\mathrm{R}_{2}$ is nearly independent of the hydrogen flow at $\mathrm{OCV}$ and $0.8 \mathrm{~V}$ (curves a and $\mathrm{c}$ of Figure 5A), and increases slightly when the $\mathrm{H}_{2}$ flow decreases at $0.6 \mathrm{~V}$ and $0.4 \mathrm{~V}$ (curves e and $\mathrm{g}$ of Figure $5 \mathrm{~A}$ ). On the contrary, $\mathrm{R}_{3}$ increases regularly when the $\mathrm{H}_{2}$ flow decreases (curves b, d, f and h of Figure 5A), suggesting that the corresponding electrochemical process, which become drastically rate-determining, is associated to anodic mass transfer, as already observed for other Fiaxell Ni/YSZ-based cells [Error! Bookmark not defined.,49,61]. At $\mathrm{OCV}$, both $\mathrm{R}_{2}$ and $\mathrm{R}_{3}$ remain independent on the $\mathrm{O}_{2}$ flow (curves a and $\mathrm{b}$ of Figure 5B), in accordance with the similarity of the slope of the corresponding $\mathrm{U}$ versus J curves (Figure 4B). On the contrary, and also in accordance with Figure 4B, when the voltage decreases, $\mathrm{R}_{2}$ and $\mathrm{R}_{3}$ become more and more dependent on the $\mathrm{O}_{2}$ flow, confirming that the associated resistances are mainly correlated to cathodic phenomena, as claimed in [24]. The influence of the $\mathrm{O}_{2}$ flow on $\mathrm{R}_{3}$ become drastic at $0.6 \mathrm{~V}$ and $0.4 \mathrm{~V}$, leading to a contribution of the electrodes to the total resistance reaching $82 \%$ when the cell is fuelled with $100 \mathrm{~mL} \mathrm{~min}^{-1}$ air flow at the air side (and $157 \mathrm{~mL} \mathrm{~min}^{-1} \mathrm{H}_{2}$ flow at the fuel side), i.e. under oxygen depletion.

\subsubsection{Influence of the operation voltage onto the ageing of the cell}

In order to further characterize the cells, experiments were achieved during several hours, by imposing a constant voltage at the cell, and plotting regularly the impedance diagram at this voltage. Figure $6 A$ presents the variations of the three resistances $R_{1}(a$ and $d), R_{2}(b$ and e) and $\mathrm{R}_{3}$ (c and $\mathrm{f}$ ) when the cell is maintained at $750^{\circ} \mathrm{C}$ at $0.8 \mathrm{~V}(\mathrm{a}, \mathrm{b}$ and $\mathrm{c}$ ) and $0.4 \mathrm{~V}(\mathrm{~d}$, e and f). Whereas at $0.4 \mathrm{~V}$ the three resistances remain constant, $\mathrm{R}_{2}$ and $\mathrm{R}_{3}$ decreases slightly at 0.8 $\mathrm{V}$, in accordance with a corresponding low increase of the current density. Whereas degradation of fuel electrodes are commonly reported, for SOFC operation at these temperatures with nickel cermet with high nickel contents or large nickel particle size [26-28], these results confirm the high quality of Fiaxell electrodes. 
Same experiments were carried out at $850^{\circ} \mathrm{C}$, and results are presented Figure 6B. If the operation at $0.8 \mathrm{~V}$ doesn't affect the values of the three resistances $\mathrm{R}_{1}, \mathrm{R}_{2}$ and $\mathrm{R}_{3}$ during at least 3 days (curves a, b and c), results at $0.4 \mathrm{~V}$ are different, with an increase of the three resistances leading to a corresponding decrease of the current density and power of the cell, suggestion a degradation of the air electrode [23]. Therefore, at this temperature, which is more convenient to reach acceptable power density values and will be used below, it is necessary to limit the decrease of the operation voltage in order to avoid rapid ageing of the cell.

\subsection{Characterization of cells working on fuel cell mode under wet air}

\subsubsection{Characterization of cells working on fuel cell mode under pure wet air}

Similar experiments were performed under wet air. Figure 7A presents the voltage (a) and power density (b) versus current density characteristics recorded for a new cell at $10 \mathrm{mV} \mathrm{s}^{-1}$ under wet $\left(3 \% \mathrm{H}_{2} \mathrm{O}\right) 62 \% \mathrm{H}_{2}-38 \%$ Ar mixture (i.e. corresponding to a $\mathrm{H}_{2}$ flow of $155 \mathrm{~mL}$ $\left.\mathrm{min}^{-1}\right)$ on the fuel side and wet $\left(3 \% \mathrm{H}_{2} \mathrm{O}\right)$ air $\left(400 \mathrm{~mL} \mathrm{~min}^{-1}\right)$ on the air side, and at $850{ }^{\circ} \mathrm{C}$. A drastic decrease of the open circuit voltage and of the power density values are observed, but a power density of $206 \mathrm{~mW} \mathrm{~cm}^{-2}$ can be reached. The shape of the $\mathrm{U}$ versus $\mathrm{J}$ curve is also very different: at origin the slope is lower, in accordance with the impedance diagram a of Figure 7B. This diagram can be fitted by the electrical equivalent circuit $\mathrm{L}+\mathrm{R}_{1}+\left(\mathrm{R}_{2} / / \mathrm{CPE}_{2}\right)$ $+\left(\mathrm{R}_{3} / / \mathrm{CPE}_{3}\right)$, with corresponding $\mathrm{R}_{2}, \mathrm{R}_{3}, \mathrm{C}_{2}$ and $\mathrm{C}_{3}$ values reported in Table $4 . \mathrm{C}_{2}$ and $\mathrm{C}_{3}$ are significantly lower than in dry air, suggesting that in this case $\mathrm{R}_{2}$ is unambiguously associated to charge transfer. $\mathrm{R}_{2}$ and $\mathrm{R}_{3}$ values are $0.18 \Omega \mathrm{cm}^{2}$ and $0.26 \Omega \mathrm{cm}^{2}$ (instead of $1.18 \Omega \mathrm{cm}^{2}$ and $0.63 \Omega \mathrm{cm}^{2}$ under dry air), leading to a total resistance which is lower than under dry air. Whereas under dry air the slope of the U/J curve decreased regularly when the current density increased, the slope of the $\mathrm{U} / \mathrm{J}$ curve is rather constant at the beginning at the curve (with a slight drop around $0.8 \mathrm{~V}$ ), and increased below $0.6 \mathrm{~V}$. These observations are in accordance with the impedance diagrams of Figure 9B: whereas the diagram $\mathrm{b}$ is nearly the same as the 
diagram a, with a $R_{2}$ decrease $\left(0.12 \Omega \mathrm{cm}^{2}\right.$ instead of $\left.0.18 \Omega \mathrm{cm}^{2}\right)$ partially balanced by a $\mathrm{R}_{3}$ increase $\left(0.30 \Omega \mathrm{cm}^{2}\right.$ instead of $\left.0.26 \Omega \mathrm{cm}^{2}\right)$, diagrams c and $\mathrm{d}$ reveals an important increase of the mass transfer phenomena, with even the appearance of an additional mass transfer phenomenon at $0.4 \mathrm{~V}$ (see Table 4).

The increase of the resistance of the cell is also correlated to an unexpected increase of $R_{l}$ when the voltage decreases, suggesting that the presence of water at the air side of the cell induces a decrease of the conductivity of the electrolyte exacerbated when the current density increases. This observation is in accordance with recent studies [62], claiming that this resistance increase is correlated to a delamination of the LSCF electrode, which is associated, in some cases, to important recrystallization and lattice shrink of the LSCF material. Moreover, these authors observed that this delamination is more important and can even be associated to an increase of the electrode resistances, when the current density increases, as we observed at $0.4 \mathrm{~V}$.

Finally, experiments were realized by maintaining the cell at $0.8 \mathrm{~V}$ during several hours, and show a good stability of the performances of the cell, with just a slight decrease of the current density, mainly due to a small increase of the electrolyte resistance, reaching $0.44 \Omega \mathrm{cm}^{2}$ (instead of $0.42 \Omega \mathrm{cm}^{2}$ ) in 18 hours. This observation is also in accordance with Pan [62], claiming that these degradation processes can be avoided, at least at low current densities, when the YSZ electrolyte is covered by a dense GDC layer, as it is the case for our cells. Curves (c) and (d) of figure 7A are obtained under wet $\left(3 \% \mathrm{H}_{2} \mathrm{O}\right) 37 \% \mathrm{H}_{2}-63 \%$ Ar mixture (i.e. corresponding to a $\mathrm{H}_{2}$ flow of $\left.55 \mathrm{~mL} \mathrm{~min}^{-1}\right)$ on the fuel side and wet $\left(3 \% \mathrm{H}_{2} \mathrm{O}\right)$ air $(200$ $\mathrm{mL} \min ^{-1}$ ) on the air side. As it was observed under dry air, the decrease of the $\mathrm{O}_{2}$ and $\mathrm{H}_{2}$ concentrations leads to an important decrease of the power density. As confirmed by impedance diagrams (Figure 7C) and corresponding fitting values of Table 4, the resistance of the cell (and the slope of the U/J curve) increases drastically below $0.8 \mathrm{~V}$, due mainly to the 
increase of mass transfer resistances, but also to an increase of the resistance of the electrolyte.

\subsubsection{Characterization of cells working on fuel cell mode under marine atmosphere}

Additional experiments were carried out, always at $850^{\circ} \mathrm{C}$ under wet $\left(3 \% \mathrm{H}_{2} \mathrm{O}\right) 37 \% \mathrm{H}_{2}-63 \%$ Ar mixture (i.e. corresponding to a $\mathrm{H}_{2}$ flow of $55 \mathrm{~mL} \mathrm{~min}^{-1}$ ) at the fuel side but under $200 \mathrm{~mL}$ $\mathrm{min}^{-1}$ air bubbling in saturated salt water at room temperature $\left(p \mathrm{H}_{2} \mathrm{O}=0.3 \mathrm{~atm}\right)$ at the air side. In this case, a drastic decrease in OCV is observed, with a simultaneous increase of the total resistance of the cell, reaching more than $4 \Omega \mathrm{cm}^{2}$. This detrimental effect of marine air onto the cell is irreversible, since after several days equilibrium under under wet $\left(3 \% \mathrm{H}_{2} \mathrm{O}\right) \mathrm{H}_{2}(155$ $\mathrm{mL} \mathrm{min}-1$ ) at the fuel side and $400 \mathrm{~mL} \mathrm{~min}^{-1}$ dry air, in spite of the recovering of the OCV, the performance of the cell remain very poor, with a maximum power density of $62 \mathrm{~mW} \mathrm{~cm}{ }^{-2}$, and, as shown in Table 5, a resistance of the cell increasing drastically when the voltage decreases, correlated to $\mathrm{R}_{1}, \mathrm{R}_{2}$ and $\mathrm{R}_{4}$ increases.

\subsection{Characterization of cells working on electrolyser mode}

\subsubsection{Characterization of cells working on electrolyser mode under dry air}

Figure 8 presents the voltage (a) and power density (b) versus current density curves obtained at $850^{\circ} \mathrm{C}$ under a $250 \mathrm{~mL} \mathrm{~min}^{-1}$ flow of dry $\left(3 \% \mathrm{H}_{2} \mathrm{O}\right) 62 \% \mathrm{H}_{2}-38 \%$ Ar mixture (i.e. corresponding to a $\mathrm{H}_{2}$ flow of $\left.155 \mathrm{~mL} \mathrm{~min}^{-1}\right)$ on the fuel side and dry air $\left(400 \mathrm{~mL} \mathrm{~min}^{-1}\right)$ on the air side, between $-0.12 \mathrm{~A} \mathrm{~cm}^{-2}$ and $+0.12 \mathrm{~A} \mathrm{~cm}^{-2}$, when plotted firstly towards negative current density values (electrolysis mode), then towards positive current density values (fuel cell mode). A power density of $125 \mathrm{~mW} \mathrm{~cm}^{-2}$ is reached at $-0.12 \mathrm{~A} \mathrm{~cm}^{-2}$. The corresponding impedance diagram plotted at $-0.12 \mathrm{~A} \mathrm{~cm}^{-2}$, i.e. in electrolysis mode, presents similarities with diagrams plotted in fuel cell mode, with $\mathrm{C}_{2}$ and $\mathrm{C}_{3}$ values of $6.110^{-4} \mathrm{~F} \mathrm{~cm}^{-2}$ and $1.610^{-1} \mathrm{~F} \mathrm{~cm}^{-}$ ${ }^{2}$, with corresponding resistances of $0.46 \Omega \mathrm{cm}^{2}$ and $0.20 \Omega \mathrm{cm}^{2}$. As shown in Figure 8 , the $\mathrm{U}$ versus $\mathrm{J}$ curve in electrolysis mode is rather linear between $0.12 \mathrm{~A} \mathrm{~cm}^{-2}$ and $-0.12 \mathrm{~A} \mathrm{~cm}^{-2}$, and the impedance diagram is the same in this entire current density range. Therefore the 
resistance of the cell at OCV measured after operation in electrolysis mode is lower than after long-time fuel cell operation, in accordance with the reactivation of cells already described in $[28]$.

If these results suggest that it is possible to work in electrolysis mode with these cell, operating conditions, with an important delivery of hydrogen on the fuel cell, doesn't correspond to effective electrolysis conditions. Indeed, experiments have been made by suppressing the pure hydrogen delivery, and fueling the cell only with $100 \mathrm{~mL} \mathrm{~min}^{-1}$ dry $(3 \%$ $\left.\mathrm{H}_{2} \mathrm{O}\right) 5 \% \mathrm{H}_{2}-95 \%$ Ar mixture (i.e. corresponding to a $\mathrm{H}_{2}$ flow of $5 \mathrm{~mL} \mathrm{~min}^{-1}$ ). In this case, the OCV drops drastically at $0.8 \mathrm{~V}$, in accordance with already published results $[20,22]$, but it is possible to set the voltage at $0.2 \mathrm{~V}$ versus $\mathrm{OCV}$ or $0.3 \mathrm{~V}$ versus $\mathrm{OCV}$, i.e. at voltages at which there is no damage of the cathode materials. In these conditions, the current density is stable, and respective power densities of $130 \mathrm{~mW} \mathrm{~cm}^{-2}$ and $200 \mathrm{~mW} \mathrm{~cm}^{-2}$ can be observed (Table 6). As shown on Table 6, it is also possible to further decrease the OCV and increase the power densities by decreasing the air supply (and consequently the oxygen one) from $400 \mathrm{~mL} \mathrm{~min} \mathrm{~m}^{-1}$ to $100 \mathrm{~mL} \mathrm{~min}^{-1}$ : in these conditions a value of $340 \mathrm{~mW} \mathrm{~cm}{ }^{-2}$ can be obtained at $0.3 \mathrm{~V}$ versus OCV. Finally additional experiments were realized by working at $850^{\circ} \mathrm{C}$ alternatively in fuel cell mode at $-0.2 \mathrm{~V}$ versus $\mathrm{OCV}$ under wet $\mathrm{H}_{2}\left(157 \mathrm{~mL} \mathrm{~min}^{-1}\right)$ on the fuel side and dry air $\left(400 \mathrm{~mL} \mathrm{~min}^{-1}\right)$ on the air side, then in electrolysis mode at $0.3 \mathrm{~V}$ versus OCV under wet $\mathrm{H}_{2}$ $\left(100 \mathrm{~mL} \mathrm{~min}^{-1}\right)$ on the fuel side and dry air $\left(100 \mathrm{~mL} \mathrm{~min}^{-1}\right)$ on the air side, and respective power density values of $300 \mathrm{~mW} \mathrm{~cm}^{-2}$ (at $-0.2 \mathrm{~V}$ vs OCV) and $340 \mathrm{~mW} \mathrm{~cm}^{-2}$ (at $0.3 \mathrm{~V} \mathrm{vs}$ OCV) are obtained reproducibly. When the same experiment is done with air bubbling in water, power density values of $200 \mathrm{~mW} \mathrm{~cm}^{-2}$ (at $-0.2 \mathrm{~V}$ vs OCV) and $340 \mathrm{~mW} \mathrm{~cm}^{-2}$ (at $0.3 \mathrm{~V}$ vs OCV) are obtained.

\subsubsection{Characterization of cells working on electrolyser mode under wet air}

Similar experiments were done under wet air, and results are given on Table 6 for comparison. If the additional presence of water at the air side seems induce a slight increase 
of the power densities recorded for an air flow of $100 \mathrm{~mL} \mathrm{~min}^{-1}$, the effect becomes negligible for $400 \mathrm{~mL} \mathrm{~min}-1$. As in SOFC mode, and in accordance with [62], operation of these type of cells is possible without drastic degradation if the current density remains low enough. Last experiments were realized under air bubbling in salt water at room temperature $\left(\mathrm{pH}_{2} \mathrm{O}=0.3\right.$ atm) at the air side. In this case, the power density values are divided by a factor 2 , and the OCV decreases drastically in some hours, forbidding ulterior measurements. Even after restoring standard conditions, i.e. $155 \mathrm{~mL} \mathrm{~min}^{-1}$ of $\mathrm{H}_{2}$ on the fuel side and $400 \mathrm{~mL} \mathrm{~min}^{-1}$ of wet $\left(3 \% \mathrm{H}_{2} \mathrm{O}\right)$ air on the air side, there is no recovering of the initial performance, suggesting that the effect of marine atmosphere is irreversible.

\section{Conclusions}

It has been demonstrated that the Ni/Yttria-stabilized zirconia (YSZ) based Fiaxell cell covered by a $\left(\mathrm{La}_{0.60} \mathrm{Sr}_{0.40}\right)_{0.95} \mathrm{Co}_{0.20} \mathrm{Fe}_{0.80} \mathrm{O}_{3-\delta}$ cathode could be successfully operated both in fuel cell and electrolysis modes alternatively, without requiring regeneration steps, and consequently offered good opportunity to be used in facilities in isolated sites just supplied by renewable energies. Impedance measurements confirmed that if at $750^{\circ} \mathrm{C}$, the cells can be used in large voltages range, at $850^{\circ} \mathrm{C}$ the cell must be operated at low current density values (or near the $\mathrm{OCV}$ ) in order to avoid degradation. It has also been shown that in the case of hydrogen or oxygen depletion, leading to power density decrease, lead nevertheless to better fuel utilization yields. Nevertheless, the cell can be further improved in order to reach higher power densities, both in electrolysis but also fuel cell modes, and studies are in progress in order to improve electrodes. Moreover, marine atmosphere seems detrimental for these cells, forbidding direct use in marine environment. Indeed simple filtering process must be added on the air side, and will be presented in a forthcoming paper.

\section{Acknowledgements}


The authors are thankful to Eurostar's funding for financial support through the European RoxSolidCell project E! 7576. 


\section{References}

[1] K. Mazloomi, C. Gomes, Renew. Sustain. Energy Rev. 2012, 16, 3024.

[2] I. Dincer, C. Acar, Int. J. Hydrogen Energy 2018, 18, 8579.

[3] Y. Zhang, R. Knibbe, J. Sunarso, Y. Zhong, W. Zhou, Z. Shao, Z. Zhu, Adv. Mater. 2017, 29, 1700132.

[4] Y. Lu, Y. Cai, L. Souamy, X. Song, L. Zhang, J. Wang, Int. J. Hydrogen Energy 2018, $43,12870$.

[5] A. Abdalla, S. Hossain, A. Azad, P. Petra, F. Begum, S. Eriksson, A. Azad, Renew. Sustain. Energy Rev. 2018, 82, 353.

[6] Z. Pan, Q. Liu, L. Zhang, J. Zhou, C. Zhang, S. Chan, Applied Energy 2017, 191, 559.

[7] Y. Zheng, Q. Li, T. Chen, W. Wu, C. Xu, W. Wang, Int. J. Hydrogen Energy 2015, 40, 2460.

[8] Y. Zheng, J. Zhou, L. Zhang, Q. Liu, Z. Pan, S. Chan, Electrochim. Acta 2018, 280, 206.

[9] M. Reytier, S. Di Iorio, A. Chatroux, M. Petitjean, J. Cren, M. De Saint Jean, J. Aicart, J. Mougin, Int. J. Hydrogen Energy 2015, 40, 11370.

[10] J. Aicart, F. Usseglio-Viretta, J. Laurencin, M. Petitjean, G. Delette, L. Dessemond, Int. J. Hydrogen Energy 2016, 41, 17233.

[11] F. Alenazey, Y. Alyousef, O. Almisned, G. Almutairi, M. Ghouse, D. Montinaro, F Ghigliazza, Int. J. Hydrogen Energy 2015, 40, 10274.

[12] H. K. Abdel-Aal, K. Zohdy, M. Mand, A. Kareem, The Open Fuel Cells Journal 2010, 3,1

[13] C. K. Lim, Q. Li, J. Zhou, Q. Sun, S. Chan, J. Power Sources 2017, 342, 79.

[14] G. Amikam, P. Nativ, Y. Gendel, Int. J. Hydrogen Energy 2018, 43, 6504. 
[15] M. Frank, R. Deja, R. Peters, L. Blum, D. Stolten, Applied Energy 2018, 217, 101.

[16] C. Graves, S. Ebbesen, S. Jensen, S. Simonsen, M. Mogensen, Nature Materials 2015, 14,239 .

[17] A. Hauch, M. Marchese, A. Lanzini, C. Graves, J. Power Sources 2018, 377, 110.

[18] D. Vrecko, M. Nerat, D. Vrancic, G. Dolanc, B. Dolenc, B. Pregel, F. Meyer, S. Fai Au, R. Makkus, Đ. Juricic, Int. J. Hydrogen Energy 2018, 43, 6352.

[19] F. Monaco, V. Tezyk, E. Siebert, S. Pylypko, B. Morel, J. Vulliet, T. Le Bihan, F. Lefebvre-Joud, J. Laurencin, Solid State Ionics 2018, 319, 234.

[20] M. B. Choi, B. Singh, E.D. Wachsman, S. J. Song, J. Power Sources 2013, 239, 361.

[21] Y. Tao, H. Nishino, S. Ashidate, H. Kokubo, M. Watanabe, H. Uchida, Electrochim. Acta 2009, 54, 3309.

[22] M. J. Lopez-Robledo, M. A. Laguna-Bercero, A. Larrea, V. M. Orera, J. Power Sources 2018, 378, 184.

[23] S. P. Jiang, Int. J. Hydrogen Energy 2019, 44, 7448.

[24] M. A. Laguna-Bercero, J. A. Kilner, S. J. Skinner, Chem. Mater. 2010, 22, 1134.

[25] O.A. Marina, L.R. Pederson, M.C. Williams, G.W. Coffey, K.D. Meinhardt, C.D. Nguyen, E.C. Thomsen, J. Electrochem. Soc. 2007, 154, B452.

[26] M. Keane, H. Fan, M. Han, P. Singh, Int. J. Hydrogen Energy 2014, 39, 18718.

[27] K. Chen, S. P. Jiang, J. Electrochem. Soc. 2016, 163, F3070.

[28] A. hauch, M. Marchese, A. Lanzini, C. Graves, J. Power Sources 2018, 377, 110.

[29] R. Ihringer, Electrochem Soc Transactions 2011, 35, 393.

[30] Fiaxell SOFC Technologies | Home, can be found under https://www.fiaxell.com, 2018

[31] S. Gao, J. Li, Z. Lin, J. Power Sources 2014, 255, 144. 
[32] M. Haydn, K. Ortner, T. Franco, S. Uhlenbruck, N. H. Menzler, D. Stöver, G. Braüer, A. Venskutonis, L. S. Sigi, H. P. Buchkremer, R. Vassen, J. Power Sources 2014, 256, 52.

[33] L. Zhang, F. Liu, K. Brinkman, K. L. Reifsnider, A. V. Virkar, J. Power Sources 2014, 247, 947.

[34] P. Coquoz, J. Ruiz, I. El Bakkali, C. Grize, A. Bourradou, S. Diethelm, V. Singh, R. Ihringer, paper OPR3-43 presented at the $6^{\text {th }}$ International Conference on Fundamentals and Development of Fuel Cells, Toulouse, France, 2015.

[35] A. Le Gal La Salle, F. Ricoul, O. Joubert, A. Kerihuel, A. Subrenat, Fuel cells 2017, 17, 144.

[36] M. Lebreton, B. Delanoue, E. Baron, F. Ricoul, A. Kerihuel, A. Subrenat, O. Joubert, A. Le Gal La Salle, Int. J. Hydrogen Energy, 2015, 40, 10231.

[37] F. Ricoul, A. Subrenat, O. Joubert, A. Le Gal La Salle, Int. J. Hydrogen Energy 2017, 42,21215 .

[38] F. Ricoul, A. Subrenat, O. Joubert, A. Le Gal La Salle, J. Solid State Electrochem. 2018, 22, 2789.

[39] Q. A. Huang, R. Hui, B. Wang, J. Zhang, Electrochim Acta 2007, 52, 8144.

[40] D. Klotz, A. Weber, E. Ivers-Tiffee, Electrochim Acta 2017, 227, 110.

[41] D. Johnson, ZView: A software program for IES analysis, Version 2.8, Scribner associates, INC, Southern Pines, NC, 2002.

[42] A. Hornes, M. J. Escudero, L. Daza, A. Martinez-Arias, J. Power Sources 2014, 249, 520.

[43] J. Qian, W. Sun, Q. Zhang, G. Jiang, W. Liu, J. Power Sources 2014, 249, 131.

[44] J. Nielsen, J. Hjelm, Electrochim. Acta 2014, 115, 31.

[45] K. S. Cole, R. H. Cole, J. Chem. Phys. 1941, 9, 341. 
[46] J.R. MacDonald, Impedance Spectroscopy Emphasizing Solid Materials and Systems, WILEY, New York, 1987.

[47] D. Marrero-Lopez, J. Pena-Martinez, J. C. Ruiz-Morales, M. Gabas, P. Nunez, M. A. G. Aranda, J. R. Ramos-Barrado, Solid St. Ionics 2010, 180, 1672.

[48] H. Ju, J. Eom, J. K. Lee, H. Choi, T. H. Lim, R. H. Song, J. Lee, Electrochim. Acta 2014, 115, 511.

[49] A. Le Gal La Salle, M. Olivon, O. Joubert, paper presented at the Journées d'Electrochimie, Bordeaux, France, 2017.

[50] N. Bonanos, paper presented at EIS-2008, 41st Heyrovsky Discussion, Caste Trest, Czech Republic, 2008.

[51] L. P. Sun, H. Zhao, Q. Li, L. H. Huo, J. P. Viricelle, C. Pijolat Int. J. Hydrogen Energy 2013, 38, 14060 .

[52] D. Marrero-Lopez, R. Romero, F. Martin, J. R. Ramos-Barrado, J. Power Sources 2014, 255, 308.

[53] D. A. Harrington, J Electroanal. Chem. 2015, 737, 30.

[54] D. Montinaro, A. R. Contino, A. Dellai, M. Rolland, Int. J. Hydrogen Energy 2014, $39,21638$.

[55] A. Leonide, V. Sonn, A. Weber, E. Ivers-Tiffee, J. Electrochem. Soc. 2008, 155, B36.

[56] E. H. Kim, H. J. Jung, K. S. An, J. Y. Park, J. Lee, I. D. Hwang, J. Y. Kim, M. J. Lee, Y. Kwon, J. H. Hwang, Ceram. Int. 2014, 40, 7817.

[57] S. Primdahl, M. Mogensen, J. Electrochem. Soc. 1999, 146, 2827.

[58] B. Philippeau, F. Mauvy, C. Mazataud, S.Fourcade, J. C. Grenier, Solid St. Ionics 2013, 249, 17.

[59] S. J. Kim, M. B. Choi, M. Park, H. Kim, J. W. Son, J. H. Lee, B. B. Kim, H. W. Lee, S. G. Kim, K. J. Yoon, J. Power Sources 2017, 360, 284. 
[60] D. Papurello, D. Menichini, A. Lanzini, Electrochim. Acta 2017, 258, 98.

[61] A. Le Gal La Salle, Y. Doury, R. Ihringer, O. Joubert, paper presented at the Réunion plénière du GdR 3652 HySPàC “Hydrogène, Systèmes et Piles à combustible”, PACEOS 3, Porticcio, France, 2015.

[62] Z. Pan, Q. Liu, R. Lyu, P. Li, S. Hwa Chan, J. Power Sources 2018, 378, 571.

\section{Figure Captions}

Figure 1. Schematic representation of the cells.

Figure 2. Experimental setup used for cell feeding and heating, showing the oven (A) and the Inconel support (B) acting as the lid of the oven and maintaining the cell in the oven (details are given in experimental section).

Figure 3. A: Voltage (a and c) and power density versus current density (b and d) characteristics recorded at $10 \mathrm{mV} \mathrm{s}^{-1}$ under dry air $\left(400 \mathrm{~mL} \mathrm{~min}^{-1}\right)$ on the air side and wet $(3 \%$ $\left.\mathrm{H}_{2} \mathrm{O}\right) \mathrm{H}_{2}\left(157 \mathrm{~mL} \mathrm{~min}^{-1}\right.$ ) fuel side at $850{ }^{\circ} \mathrm{C}$ (a and b) and $750{ }^{\circ} \mathrm{C}$ (c and d). B: Nyquist diagrams recorded at $850{ }^{\circ} \mathrm{C}$ (a) and $750{ }^{\circ} \mathrm{C}$ (b) under dry air $\left(400 \mathrm{~mL} \mathrm{~min}^{-1}\right)$ on the air side and wet $\left(3 \% \mathrm{H}_{2} \mathrm{O}\right) \mathrm{H}_{2}\left(157 \mathrm{~mL} \mathrm{~min}^{-1}\right)$ fuel side. Numbers mentioned above the diagram are the frequency values.

Figure 4. A: Voltage (a, b and c) and power density versus current density (a', b' and c') characteristics recorded at $10 \mathrm{mV} \mathrm{s}^{-1}$ under dry air $\left(400 \mathrm{~mL} \mathrm{~min}^{-1}\right)$ on the air side and wet $(3 \%$ $\mathrm{H}_{2} \mathrm{O}$ ) $\mathrm{H}_{2}$ (a and a': $107 \mathrm{~mL} \mathrm{~min}^{-1}$, b and b': $83 \mathrm{~mL} \mathrm{~min}^{-1}$, and $\mathrm{c}$ and $\mathrm{c}^{\prime}: 57 \mathrm{~mL} \mathrm{~min}^{-1}$ ) on the fuel side, at $850{ }^{\circ} \mathrm{C}$ and $\mathrm{B}$ : Voltage (d, e and f) and power density versus current density (d', $\mathrm{e}^{\prime}$ and $\mathrm{f}^{\prime}$ ) characteristics recorded at $10 \mathrm{mV} \mathrm{s}^{-1}$ under dry air ( $\mathrm{d}$ and d': $300 \mathrm{~mL} \mathrm{~min}^{-1}$, e and e':

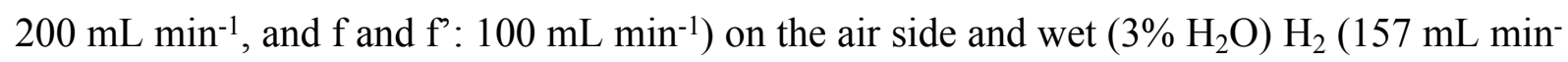
${ }^{1}$ ) on the fuel side, at $850^{\circ} \mathrm{C}$. Corresponding Nyquist (C) and Bode (D) diagrams recorded at $850{ }^{\circ} \mathrm{C}$ at $\mathrm{OCV}$ under dry air (a, b and c: $400 \mathrm{~mL} \mathrm{~min}^{-1}$, d: $300 \mathrm{~mL} \mathrm{~min}{ }^{-1}$, e: $200 \mathrm{~mL} \mathrm{~min}{ }^{-1}$, f: 
$\left.100 \mathrm{~mL} \mathrm{~min}^{-1}\right)$ on the air side and wet $\left(3 \% \mathrm{H}_{2} \mathrm{O}\right) \mathrm{H}_{2}\left(\mathrm{a}: 107 \mathrm{~mL} \mathrm{~min}^{-1}\right.$, b: $83 \mathrm{~mL} \mathrm{~min}^{-1}$, c: 57 $\mathrm{mL} \min ^{-1}$, d, e and f: $157 \mathrm{~mL} \mathrm{~min}^{-1}$ ) on the fuel side, at $850{ }^{\circ} \mathrm{C}$. Numbers mentioned above the diagrams of Figure $\mathrm{C}$ are the frequency values.

Figure 5 A: Variations of the resistance $R_{2}$ (a, c, e and $g$ ) and $R_{3}(b, d, f$ and $h)$ values determined from impedance diagrams recorded at $850{ }^{\circ} \mathrm{C}$ under dry air $\left(400 \mathrm{~mL} \mathrm{~min}^{-1}\right)$ on the air side with the flow rate of wet $\left(3 \% \mathrm{H}_{2} \mathrm{O}\right) \mathrm{H}_{2}$ fueling the fuel side at $O C V(\mathrm{a}$ and b), at $0.8 \mathrm{~V}$ (c and d), 0.6 V (e and f) and $0.4 \mathrm{~V}$ (g and h). B: Variations of the resistance $\mathrm{R}_{2}(\mathrm{a}, \mathrm{c}, \mathrm{e}$ and $\mathrm{g}$ ) and $\mathrm{R}_{3}(\mathrm{~b}, \mathrm{~d}, \mathrm{f}$ and $\mathrm{h})$ values determined from impedance diagrams recorded at $850{ }^{\circ} \mathrm{C}$ under wet $\left(3 \% \mathrm{H}_{2} \mathrm{O}\right) \mathrm{H}_{2}\left(157 \mathrm{~mL} \mathrm{~min}^{-1}\right)$ on the fuel side with the flow rate of dry air fueling the air side at $O C V$ (a and b), at $0.8 \mathrm{~V}$ (c and d), $0.6 \mathrm{~V}(\mathrm{e}$ and $\mathrm{f}$ ) and $0.4 \mathrm{~V}$ (g and h).

Figure 6. Variations with time of three resistances $R_{l}$ (a and d), $\mathrm{R}_{2}\left(\mathrm{~b}\right.$ and e) and $\mathrm{R}_{3}$ (c and $\mathrm{f}$ ) values determined from impedance diagrams recorded when the cell is maintained at $0.8 \mathrm{~V}$ (a, $\mathrm{b}$ and $\mathrm{c})$ or $0.4 \mathrm{~V}(\mathrm{~d}$, e and $\mathrm{f})$ under dry air $\left(400 \mathrm{~mL} \mathrm{~min}^{-1}\right)$ on the air side and wet $\left(3 \% \mathrm{H}_{2} \mathrm{O}\right)$ $\mathrm{H}_{2}\left(153 \mathrm{~mL} \mathrm{~min}^{-1}\right)$ on the air side, at $750^{\circ} \mathrm{C}(\mathrm{A})$ and $850^{\circ} \mathrm{C}(\mathrm{B})$.

Figure 7. A: Voltage (a and c) and power density (b and d) versus current density characteristics recorded at $850^{\circ} \mathrm{C}$ and $10 \mathrm{mV} \mathrm{s}^{-1}$ under wet air $(400 \mathrm{~mL} \mathrm{~min}-1)$ on the air side and wet $\left(3 \% \mathrm{H}_{2} \mathrm{O}\right) \mathrm{H}_{2}\left(155 \mathrm{~mL} \mathrm{~min}^{-1}\right)$ on fuel side (a and b) and under wet air $(200 \mathrm{~mL} \mathrm{~min}-1)$ on the air side and wet $\left(3 \% \mathrm{H}_{2} \mathrm{O}\right) \mathrm{H}_{2}\left(55 \mathrm{~mL} \mathrm{~min}^{-1}\right)$ on the fuel side (c and d). Nyquist diagrams recorded at $850^{\circ} \mathrm{C}$ and $10 \mathrm{mV} \mathrm{s}^{-1}$ under wet air $\left(400 \mathrm{~mL} \mathrm{~min}^{-1}\right)$ on the air side and wet $\left(3 \% \mathrm{H}_{2} \mathrm{O}\right) \mathrm{H}_{2}\left(155 \mathrm{~mL} \mathrm{~min}^{-1}\right)$ on fuel side (B) and under wet air $\left(200 \mathrm{~mL} \mathrm{~min}^{-1}\right)$ on the air side and wet $\left(3 \% \mathrm{H}_{2} \mathrm{O}\right) \mathrm{H}_{2}\left(55 \mathrm{~mL} \mathrm{~min}^{-1}\right)$ on the fuel side $(\mathrm{C})$, and at $\mathrm{OCV}(\mathrm{a}), 0.8 \mathrm{~V}$ (b), 0.6 $\mathrm{V}(\mathrm{c})$ and $0.4 \mathrm{~V}(\mathrm{~d})$. Numbers mentioned above the diagram are the frequency values.

Figure 8. Voltage (a) and power density (b) versus current density characteristics recorded at $850^{\circ} \mathrm{C}$ and $10 \mathrm{mV} \mathrm{s}^{-1}$ under a $250 \mathrm{~mL} \mathrm{~min}^{-1}$ flow of dry $\left(3 \% \mathrm{H}_{2} \mathrm{O}\right) 62 \% \mathrm{H}_{2}-38 \%$ Ar mixture 
(i.e. corresponding to a $\mathrm{H}_{2}$ flow of $\left.155 \mathrm{~mL} \mathrm{~min}^{-1}\right)$ on the fuel side and dry air (400 $\left.\mathrm{mL} \mathrm{min}^{-1}\right)$ on the air side, between $-0.12 \mathrm{~A} \mathrm{~cm}^{-2}$ and $+0.12 \mathrm{~A} \mathrm{~cm}^{-2}$.

\section{Table Captions}

Table 1: Values of $\mathrm{R}_{1}, \mathrm{R}_{2}, \mathrm{R}_{3}, \mathrm{C}_{2}$ and $\mathrm{C}_{3}$ determined from impedance diagrams recorded when the cell is operating under $\mathrm{H}_{2}\left(157 \mathrm{~mL} \mathrm{~min}^{-1}\right)$ on the fuel side and dry air $\left(400 \mathrm{~mL} \mathrm{~min}^{-1}\right)$ on the air side, at different temperatures and different voltages.

Table 2: Values of the maximum power density recorded at $850^{\circ} \mathrm{C}$ for different providing conditions.

Table 3: Values of $\mathrm{R}_{2}, \mathrm{R}_{3}, \mathrm{C}_{2}$ and $\mathrm{C}_{3}$ determined from impedance diagrams recorded at $850^{\circ} \mathrm{C}$ for different wet $\mathrm{H}_{2}$ and dry air flow rates.

Table 4: Values of $\mathrm{R}_{2}, \mathrm{R}_{3}, \mathrm{R}_{4}, \mathrm{C}_{2}, \mathrm{C}_{3}$ and $\mathrm{C}_{4}$ determined from impedance diagrams recorded at $850^{\circ} \mathrm{C}$ for different wet $\mathrm{H}_{2}$ and wet air flow rates.

Table 5: Values of $\mathrm{R}_{2}, \mathrm{R}_{3}, \mathrm{R}_{4}, \mathrm{C}_{2}, \mathrm{C}_{3}$ and $\mathrm{C}_{4}$ determined from impedance diagrams recorded at $850^{\circ} \mathrm{C}$ for different wet $\mathrm{H}_{2}$ and dry air flow rates after operation under wet air.

Table 6: Values of power densities measured at $0.2 \mathrm{~V} / \mathrm{OCV}$ and $0.3 \mathrm{~V} / \mathrm{OCV}$ for different providing conditions. 


\section{Tables}

Table 1: Values of $\mathrm{R}_{1}, \mathrm{R}_{2}, \mathrm{R}_{3}, \mathrm{C}_{2}$ and $\mathrm{C}_{3}$ determined from impedance diagrams recorded when the cell is operating under $\mathrm{H}_{2}\left(157 \mathrm{~mL} \mathrm{~min}^{-1}\right)$ on the fuel side and dry air $\left(400 \mathrm{~mL} \mathrm{~min}^{-1}\right)$ on the air side, at different temperatures and different voltages.

\begin{tabular}{ccccccc}
\hline $\mathbf{T} /{ }^{\circ} \mathbf{C}$ & Voltage & $\mathbf{R}_{\mathbf{1}} / \mathbf{\Omega} \mathbf{~ c m}^{\mathbf{2}}$ & $\mathbf{R}_{\mathbf{2}} / \mathbf{\Omega} \mathbf{~ c m}^{\mathbf{2}}$ & $\mathbf{C}_{\mathbf{2}} / \mathbf{F} \mathbf{~ c m}^{-\mathbf{2}}$ & $\mathbf{R}_{\mathbf{3}} / \mathbf{\Omega} \mathbf{~ m}^{\mathbf{2}}$ & $\mathbf{C}_{\mathbf{3}} / \mathbf{F ~} \mathbf{~ c m}^{-\mathbf{2}}$ \\
\hline \multirow{5}{*}{850} & OCV & 0.39 & 1.18 & $1.810^{-4}$ & 0.63 & $0.510^{-1}$ \\
\cline { 2 - 7 } & $0.8 \mathrm{~V}$ & 0.43 & 0.38 & $2.110^{-4}$ & 0.16 & $1.110^{-1}$ \\
\cline { 2 - 7 } & $0.6 \mathrm{~V}$ & 0.40 & 0.13 & $7.610^{-4}$ & 0.12 & $1.910^{-1}$ \\
\cline { 2 - 7 } & $0.4 \mathrm{~V}$ & 0.40 & 0.12 & $5.510^{-4}$ & 0.14 & $3.610^{-1}$ \\
\hline \multirow{3}{*}{750} & OCV & 3.27 & 3.46 & $1.410^{-4}$ & 6.16 & $0.310^{-1}$ \\
\cline { 2 - 7 } & $0.8 \mathrm{~V}$ & 3.43 & 2.02 & $1.210^{-4}$ & 2.50 & $0.410^{-1}$ \\
\cline { 2 - 7 } & $0.6 \mathrm{~V}$ & 3.46 & 1.63 & $1.210^{-4}$ & 1.54 & $0.310^{-1}$ \\
\cline { 2 - 7 } & $0.4 \mathrm{~V}$ & 3.37 & 0.87 & $0.910^{-4}$ & 0.70 & $0.410^{-1}$ \\
\hline
\end{tabular}

Table 2: Values of the maximum power density recorded at $850^{\circ} \mathrm{C}$ for different providing conditions.

\begin{tabular}{ccc}
\hline $\mathbf{H}_{\mathbf{2}} / \mathbf{~} \mathbf{L} \mathbf{~ m i n}^{\mathbf{- 1}}$ & Air $/ \mathbf{~} \mathbf{L} \mathbf{~ m i n}^{\mathbf{- 1}}$ & $\mathbf{P}_{\mathbf{m a x}} / \mathbf{~} \mathbf{W} \mathbf{~ c m}^{\mathbf{2}}$ \\
\hline 107 & 400 & 308 \\
\hline 83 & 400 & 289 \\
\hline 57 & 400 & 253 \\
\hline 157 & 300 & 328 \\
\hline 157 & 200 & 292 \\
\hline 157 & 100 & 189 \\
\hline
\end{tabular}


Table 3: Values of $\mathrm{R}_{2}, \mathrm{R}_{3}, \mathrm{C}_{2}$ and $\mathrm{C}_{3}$ determined from impedance diagrams recorded at $850^{\circ} \mathrm{C}$ for different wet $\mathrm{H}_{2}$ and dry air flow rates.

\begin{tabular}{|c|c|c|c|c|c|}
\hline $\begin{array}{l}\text { Polarization } \\
\text { conditions }\end{array}$ & $\begin{array}{c}\text { Air-H } \\
/ \text { mL } \text { min }^{-1}-\mathbf{m L ~ m i n}^{-1}\end{array}$ & $R_{2} / \Omega \mathrm{cm}^{2}$ & $\mathrm{C}_{2} / \mathrm{F} \mathrm{\textrm {cm } ^ { - 2 }}$ & $\mathbf{R}_{3} / \Omega \mathrm{cm}^{2}$ & $\mathrm{C}_{3} / \mathrm{F} \mathrm{cm}^{-2}$ \\
\hline \multirow{6}{*}{$\mathrm{OCV}$} & $400-107$ & 1.11 & $1.910^{-4}$ & 0.81 & $0.510^{-1}$ \\
\hline & $400-83$ & 1.10 & $1.910^{-4}$ & 0.93 & $0.510^{-1}$ \\
\hline & $400-57$ & 1.13 & $1.710^{-4}$ & 1.12 & $0.610^{-1}$ \\
\hline & $300-157$ & 1.10 & $2.110^{-4}$ & 0.66 & $0.510^{-1}$ \\
\hline & $200-157$ & 1.15 & $1.910^{-4}$ & 0.63 & $0.510^{-1}$ \\
\hline & $100-157$ & 1.06 & $2.310^{-4}$ & 0.73 & $0.510^{-1}$ \\
\hline \multirow{6}{*}{$0.8 \mathrm{~V}$} & $400-107$ & 0.44 & $1.610^{-4}$ & 0.19 & $1.410^{-1}$ \\
\hline & $400-83$ & 0.45 & $1.310^{-4}$ & 0.22 & $1.110^{-1}$ \\
\hline & $400-57$ & 0.49 & $1.410^{-4}$ & 0.25 & $1.610^{-1}$ \\
\hline & $300-157$ & 0.39 & $2.510^{-4}$ & 0.15 & $1.510^{-1}$ \\
\hline & $200-157$ & 0.49 & $1.210^{-4}$ & 0.17 & $4.010^{-1}$ \\
\hline & $100-157$ & 0.54 & $5.610^{-4}$ & 0.33 & $1.510^{-1}$ \\
\hline \multirow{6}{*}{$0.6 \mathrm{~V}$} & $400-107$ & 0.14 & $8.610^{-4}$ & 0.13 & $2.610^{-1}$ \\
\hline & $400-83$ & 0.15 & $8.610^{-4}$ & 0.16 & $2.710^{-1}$ \\
\hline & $400-57$ & 0.26 & $2.210^{-4}$ & 0.24 & $2.710^{-1}$ \\
\hline & $300-157$ & 0.12 & $9.410^{-4}$ & 0.14 & $2.310^{-1}$ \\
\hline & $200-157$ & 0.14 & $9.010^{-4}$ & 0.24 & $3.310^{-1}$ \\
\hline & $100-157$ & 0.34 & $11.910^{-4}$ & 0.88 & $6.710^{-1}$ \\
\hline \multirow{6}{*}{$0.4 \mathrm{~V}$} & $400-107$ & 0.13 & $5.810^{-4}$ & 0.20 & $2.810^{-1}$ \\
\hline & $400-83$ & 0.15 & $4.110^{-4}$ & 0.35 & $2.310^{-1}$ \\
\hline & $400-57$ & 0.25 & $3.810^{-4}$ & 0.88 & $1.510^{-1}$ \\
\hline & $300-157$ & 0.08 & $3.010^{-4}$ & 0.23 & $3.710^{-1}$ \\
\hline & $200-157$ & 0.14 & $2.310^{-4}$ & 0.67 & $5.110^{-1}$ \\
\hline & $100-157$ & 0.27 & $2.110^{-4}$ & 1.59 & $4.510^{-1}$ \\
\hline
\end{tabular}

Table 4: Values of $\mathrm{R}_{2}, \mathrm{R}_{3}, \mathrm{R}_{4}, \mathrm{C}_{2}, \mathrm{C}_{3}$ and $\mathrm{C}_{4}$ determined from impedance diagrams recorded at $850^{\circ} \mathrm{C}$ for different wet $\mathrm{H}_{2}$ and wet air flow rates.

\begin{tabular}{|c|c|c|c|c|c|c|c|c|}
\hline $\begin{array}{l}\text { Wet air-H } \\
\text { / mL min } \\
\text { - mL } \text { min }^{-1}\end{array}$ & Voltage & $\begin{array}{c}\mathbf{R}_{\mathbf{1}} \\
/ \Omega \mathbf{c m}^{2}\end{array}$ & $\begin{array}{c}\mathbf{R}_{2} \\
/ \Omega \mathbf{c m}^{2}\end{array}$ & 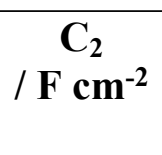 & $\begin{array}{c}\mathbf{R}_{\mathbf{3}} \\
/ \Omega \mathbf{c m}^{2}\end{array}$ & $\begin{array}{l}\mathrm{C}_{3} \\
/ \mathrm{F} \mathbf{c m}^{-2}\end{array}$ & $\begin{array}{c}\mathbf{R}_{\mathbf{4}} \\
/ \Omega \mathbf{c m}^{2}\end{array}$ & $\begin{array}{c}\mathrm{C}_{4} \\
/ \mathbf{F} \mathbf{c m}^{-2}\end{array}$ \\
\hline \multirow{4}{*}{$400-155$} & $\mathrm{OCV}$ & 0.43 & 0.18 & $1.610^{-5}$ & 0.26 & $5.110^{-3}$ & & \\
\hline & $0.8 \mathrm{~V}$ & 0.42 & 0.12 & $1.810^{-5}$ & 0.30 & $5.010^{-4}$ & & \\
\hline & $0.6 \mathrm{~V}$ & 0.47 & 0.04 & $6.010^{-5}$ & 0.48 & $8.610^{-4}$ & & \\
\hline & $0.4 \mathrm{~V}$ & 0.51 & 0.04 & $3.810^{-5}$ & 0.42 & $1.010^{-3}$ & 0.10 & $1.310^{-1}$ \\
\hline \multirow{3}{*}{$200-55$} & $\mathrm{OCV}$ & 0.50 & 0.24 & $1.210^{-5}$ & 0.36 & $6.910^{-4}$ & & \\
\hline & $0.8 \mathrm{~V}$ & 0.51 & 0.24 & $1.110^{-4}$ & 0.36 & $7.1 \quad 10^{-4}$ & & \\
\hline & $0.6 \mathrm{~V}$ & 0.64 & 0.10 & $3.810^{-5}$ & 0.69 & $1.110^{-3}$ & & \\
\hline
\end{tabular}




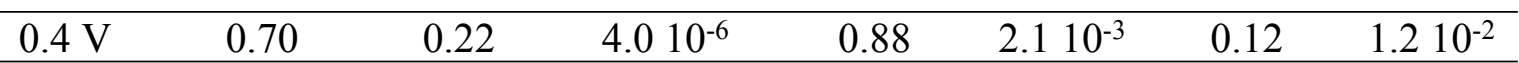

Table 5: Values of $\mathrm{R}_{2}, \mathrm{R}_{3}, \mathrm{R}_{4}, \mathrm{C}_{2}, \mathrm{C}_{3}$ and $\mathrm{C}_{4}$ determined from impedance diagrams recorded at $850^{\circ} \mathrm{C}$ for different wet $\mathrm{H}_{2}$ and dry air flow rates after operation under wet air.

\begin{tabular}{|c|c|c|c|c|c|c|c|c|}
\hline $\begin{array}{c}\text { Dry air-H } \\
\text { / }{\text { mL } \text { min }^{-1}}^{-} \\
\text {mL } \text { min }^{-1} \text { ) }\end{array}$ & Voltage & $\begin{array}{c}\mathbf{R}_{1} \\
/ \Omega \mathbf{c m}^{2}\end{array}$ & $\begin{array}{c}\mathbf{R}_{2} \\
/ \Omega \mathbf{c m}^{2}\end{array}$ & $\begin{array}{c}\mathbf{C}_{2} \\
/ \mathbf{F} \mathbf{c m}^{-2}\end{array}$ & $\begin{array}{c}\mathbf{R}_{\mathbf{3}} \\
/ \Omega \mathbf{c m}^{2}\end{array}$ & $\begin{array}{c}\mathrm{C}_{3} \\
/ \mathrm{F} \mathbf{c m}^{-2}\end{array}$ & $\begin{array}{c}\mathbf{R}_{\mathbf{4}} \\
/ \Omega \mathbf{c m}^{2}\end{array}$ & 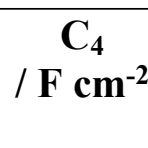 \\
\hline \multirow{4}{*}{$400-155$} & $\mathrm{OCV}$ & 0.79 & 0.57 & $7.610^{-6}$ & 0.52 & $4.510^{-4}$ & & \\
\hline & $0.8 \mathrm{~V}$ & 0.80 & 0.38 & $8.710^{-6}$ & 0.56 & $3.410^{-4}$ & & \\
\hline & $0.6 \mathrm{~V}$ & 0.84 & 0.78 & $1.610^{-6}$ & 0.67 & $3.910^{-4}$ & 0.53 & $5.110^{-2}$ \\
\hline & $0.4 \mathrm{~V}$ & 0.85 & 1.02 & $0.910^{-6}$ & 0.51 & $5.710^{-4}$ & 0.91 & $1.910^{-2}$ \\
\hline
\end{tabular}

Table 6: Values of power densities measured at $0.2 \mathrm{~V}$ (versus OCV) and $0.3 \mathrm{~V}$ (versus OCV) for different providing conditions.

\begin{tabular}{|c|c|c|c|c|}
\hline $\begin{array}{c}\text { Voltage } \\
\text { / V (vs OCV) }\end{array}$ & $\begin{array}{l}\text { Dry air - Wet } \mathrm{H}_{2} 5 \% \\
\text { / } \mathrm{mL} \text { min }^{-1}-\mathrm{mL} \text { min }^{-1}\end{array}$ & 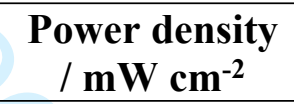 & $\begin{array}{l}\text { Wet air - Wet } \mathrm{H}_{2} 5 \% \\
\text { / } \mathrm{mL} \text { min }^{-1} \text { - mL } \text { min }^{-1}\end{array}$ & $\begin{array}{l}\text { Power density } \\
/ \mathrm{mW} \mathrm{cm}^{-2}\end{array}$ \\
\hline \multirow{2}{*}{0.2} & $400 / 100$ & 130 & $400 / 100$ & 170 \\
\hline & $100 / 100$ & 260 & $100 / 100$ & 256 \\
\hline \multirow{2}{*}{0.3} & $400 / 100$ & 200 & $400 / 100$ & 230 \\
\hline & $100 / 100$ & 340 & $100 / 100$ & 340 \\
\hline
\end{tabular}




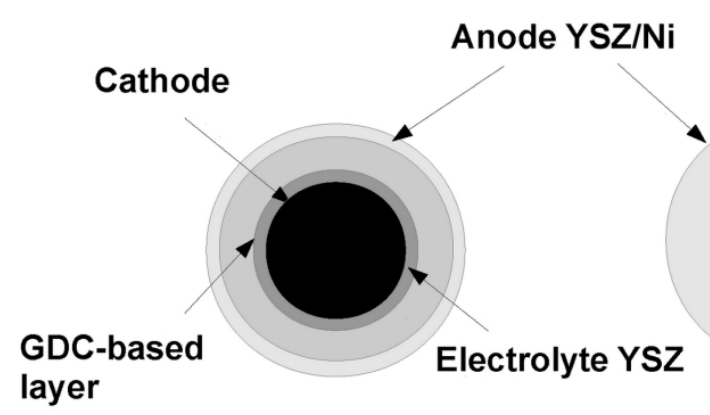

Front

Back

Figure 1. Schematic representation of the cells.

$187 \times 132 \mathrm{~mm}$ ( $350 \times 350$ DPI)

Wiley-VCH 


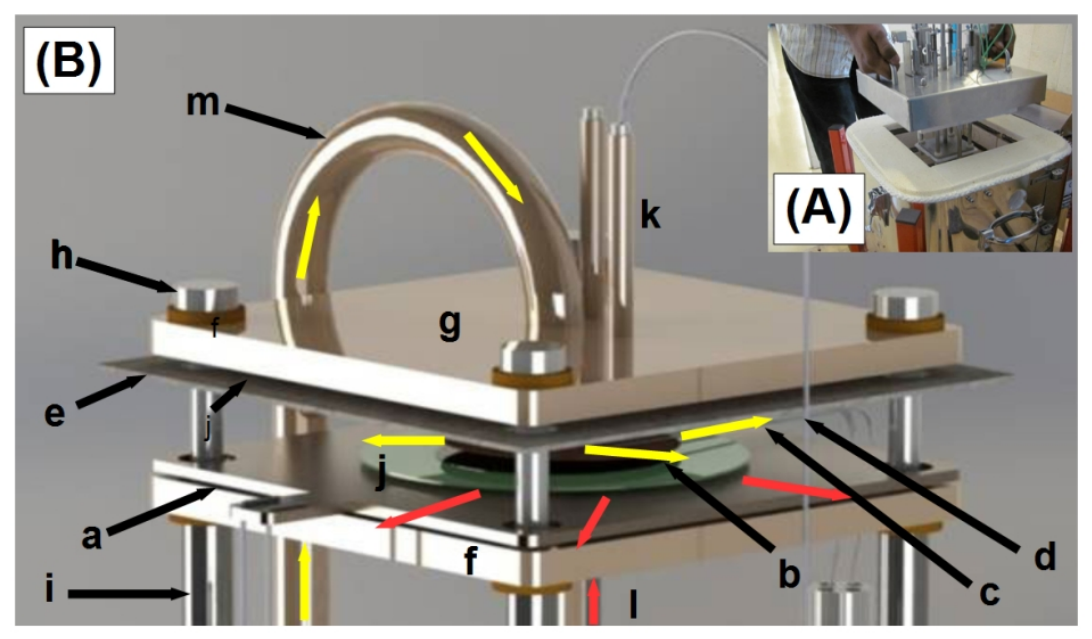

Figure 2. Experimental setup used for cell feeding and heating, showing the oven $(A)$ and the Inconel support (B) acting as the lid of the oven and maintaining the cell in the oven (details are given in experimental section).

$$
44 \times 31 \mathrm{~mm}(800 \times 800 \mathrm{DPI})
$$



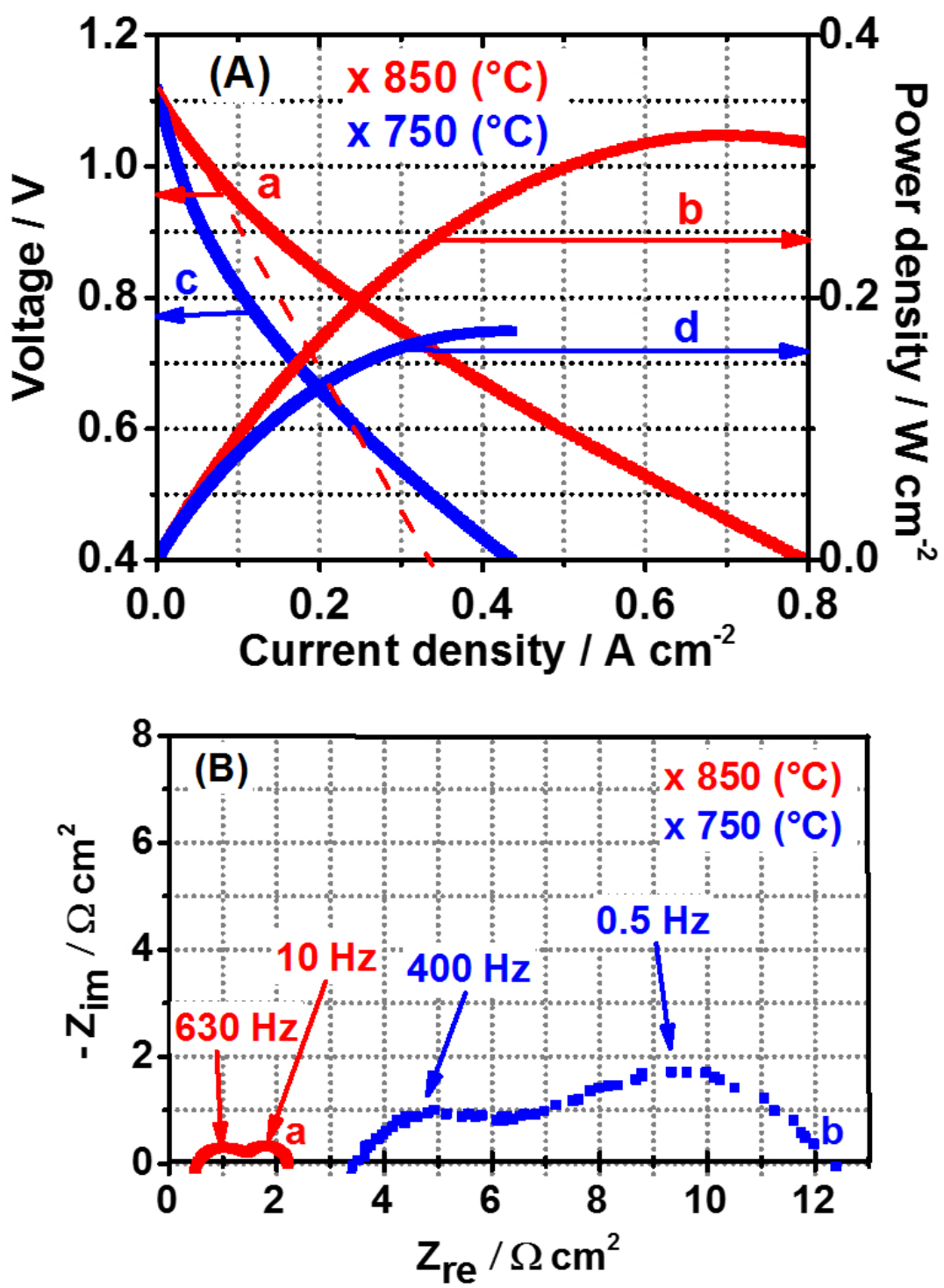

Figure 3. A: Voltage ( $a$ and $c$ ) and power density versus current density ( $b$ and $d$ ) characteristics recorded at $10 \mathrm{mV} \mathrm{s}-1$ under dry air $(400 \mathrm{~mL}$ min-1) on the air side and wet $(3 \% \mathrm{H} 2 \mathrm{O}) \mathrm{H} 2(157 \mathrm{~mL}$ min-1) fuel side at $850{ }^{\circ} \mathrm{C}(\mathrm{a}$ and $\mathrm{b})$ and $750^{\circ} \mathrm{C}(\mathrm{c}$ and $\mathrm{d})$. B: Nyquist diagrams recorded at $8500^{\circ} \mathrm{C}(\mathrm{a})$ and $750{ }^{\circ} \mathrm{C}(\mathrm{b})$ under dry air (400 mL min-1) on the air side and wet (3\% H2O) H2 (157 mL min-1) fuel side. Numbers mentioned above the diagram are the frequency values.

$42 \times 56 \mathrm{~mm}(500 \times 500 \mathrm{DPI})$ 


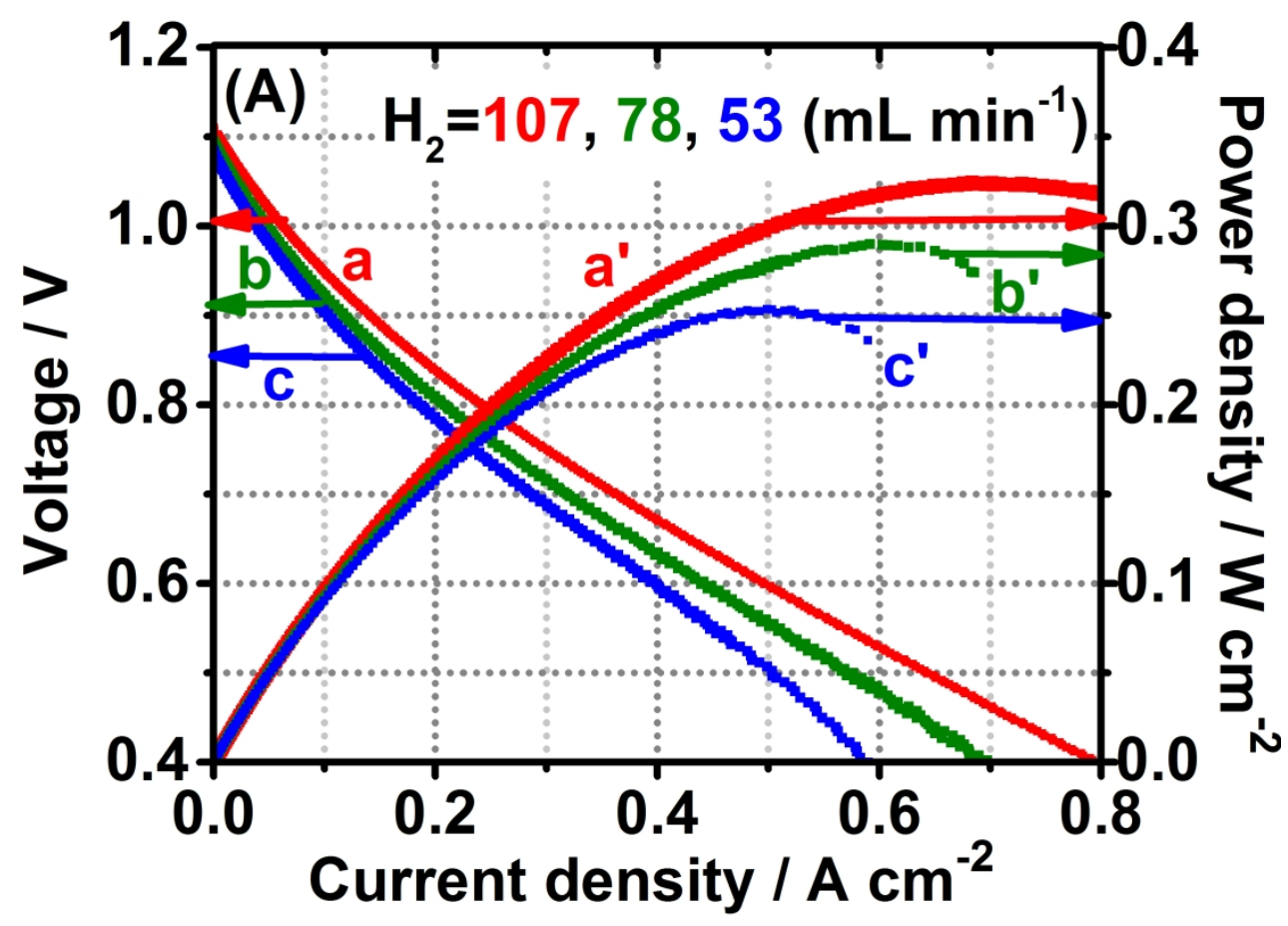

Figure 4. A: Voltage ( $a, b$ and $c)$ and power density versus current density $\left(a^{\prime}, b^{\prime}\right.$ and $\left.c^{\prime}\right)$ characteristics recorded at $10 \mathrm{mV} \mathrm{s}-1$ under dry air $(400 \mathrm{~mL}$ min-1) on the air side and wet (3\% $\mathrm{H} 2 \mathrm{O}) \mathrm{H} 2$ (a and a': 107 $\mathrm{mL} \min -1, b$ and $b^{\prime}: 83 \mathrm{~mL} \mathrm{~min}-1$, and $\mathrm{c}$ and $\mathrm{c}^{\prime}: 57 \mathrm{~mL} \mathrm{~min}-1$ ) on the fuel side, at $850{ }^{\circ} \mathrm{C}$ and $\mathrm{B}$ : Voltage (d, e and $f$ ) and power density versus current density ( $d^{\prime}, e^{\prime}$ and $\left.f^{\prime}\right)$ characteristics recorded at $10 \mathrm{mV} \mathrm{s}-1$ under dry air ( $d$ and $d^{\prime}: 300 \mathrm{~mL}$ min-1, e and $e^{\prime}: 200 \mathrm{~mL}$ min-1, and $\mathrm{f}$ and $\mathrm{f}^{\prime}: 100 \mathrm{~mL} \mathrm{~min}-1$ ) on the air side and wet $(3 \% \mathrm{H} 2 \mathrm{O}) \mathrm{H} 2\left(157 \mathrm{~mL}\right.$ min-1) on the fuel side, at $850^{\circ} \mathrm{C}$. Corresponding Nyquist (C) and Bode (D) diagrams recorded at $850^{\circ} \mathrm{C}$ at OCV under dry air $(a, b$ and $c: 400 \mathrm{~mL} \mathrm{~min}-1, \mathrm{~d}: 300 \mathrm{~mL} \mathrm{~min}-1, \mathrm{e}: 200 \mathrm{~mL}$ min-1, f: $100 \mathrm{~mL}$ min-1) on the air side and wet ( $3 \% \mathrm{H} 2 \mathrm{O}) \mathrm{H} 2$ (a: $107 \mathrm{~mL} \mathrm{~min}-1, \mathrm{~b}: 83 \mathrm{~mL} \mathrm{~min}-1, \mathrm{c}: 57 \mathrm{~mL}$ min-1, d, e and f: $157 \mathrm{~mL} \mathrm{min-1)} \mathrm{on} \mathrm{the} \mathrm{fuel} \mathrm{side,} \mathrm{at} 850^{\circ} \mathrm{C}$. Numbers mentioned above the diagrams of Figure $\mathrm{C}$ are the frequency values.

$163 \times 125 \mathrm{~mm}(500 \times 500 \mathrm{DPI})$ 


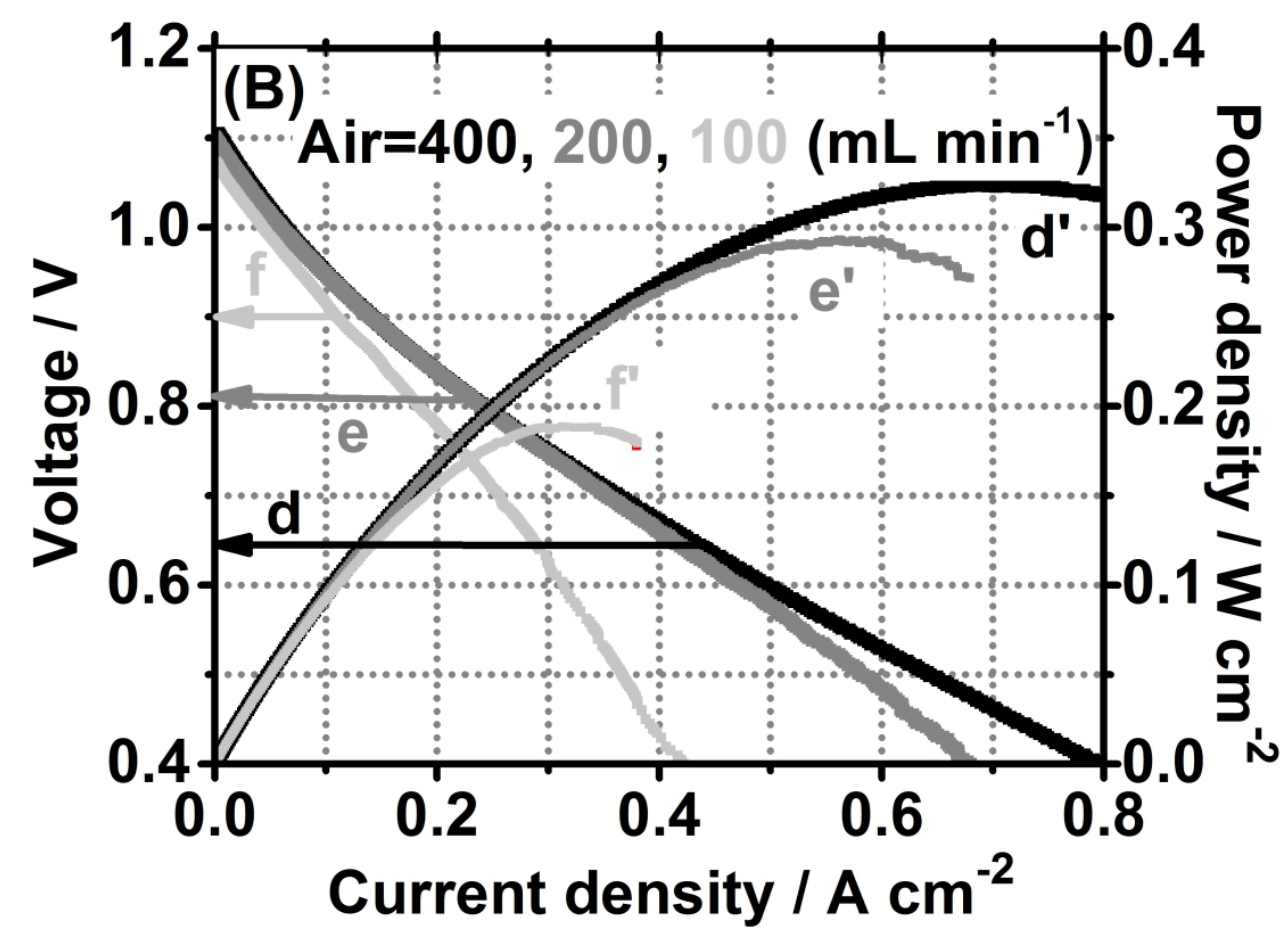

Figure 4. A: Voltage ( $a, b$ and $c)$ and power density versus current density $\left(a^{\prime}, b^{\prime}\right.$ and $\left.c^{\prime}\right)$ characteristics recorded at $10 \mathrm{mV} \mathrm{s}-1$ under dry air $(400 \mathrm{~mL} \mathrm{min-1)}$ on the air side and wet ( $3 \% \mathrm{H} 2 \mathrm{O}) \mathrm{H} 2$ (a and $\mathrm{a}^{\prime}: 107$ $\mathrm{mL} \min -1$, $b$ and $b^{\prime}: 83 \mathrm{~mL} \min -1$, and $c$ and $c^{\prime}: 57 \mathrm{~mL} \mathrm{~min}-1$ ) on the fuel side, at $850^{\circ} \mathrm{C}$ and $\mathrm{B}$ : Voltage ( $\mathrm{d}$, e and $f$ ) and power density versus current density ( $d^{\prime}, e^{\prime}$ and $\left.f^{\prime}\right)$ characteristics recorded at $10 \mathrm{mV} \mathrm{s}-1$ under dry air ( $d$ and $d^{\prime}: 300 \mathrm{~mL}$ min-1, e and $e^{\prime}: 200 \mathrm{~mL}$ min-1, and $f$ and $f^{\prime}: 100 \mathrm{~mL}$ min-1) on the air side and wet $(3 \% \mathrm{H} 2 \mathrm{O}) \mathrm{H} 2\left(157 \mathrm{~mL}\right.$ min-1) on the fuel side, at $850^{\circ} \mathrm{C}$. Corresponding Nyquist (C) and Bode (D) diagrams recorded at $850^{\circ} \mathrm{C}$ at OCV under dry air ( $a, b$ and $c: 400 \mathrm{~mL} \mathrm{~min}-1, \mathrm{~d}: 300 \mathrm{~mL} \mathrm{~min}-1$, e: $200 \mathrm{~mL}$ min-1, f: $100 \mathrm{~mL}$ min-1) on the air side and wet ( $3 \% \mathrm{H} 20$ ) H2 (a: $107 \mathrm{~mL} \mathrm{min-1,} \mathrm{b:} 83 \mathrm{~mL} \mathrm{min-1,c:57} \mathrm{mL}$ $\min -1, d$, e and $\mathrm{f}: 157 \mathrm{~mL} \mathrm{min-1)}$ on the fuel side, at $850^{\circ} \mathrm{C}$. Numbers mentioned above the diagrams of Figure $\mathrm{C}$ are the frequency values.

$163 \times 125 \mathrm{~mm}(500 \times 500$ DPI) 


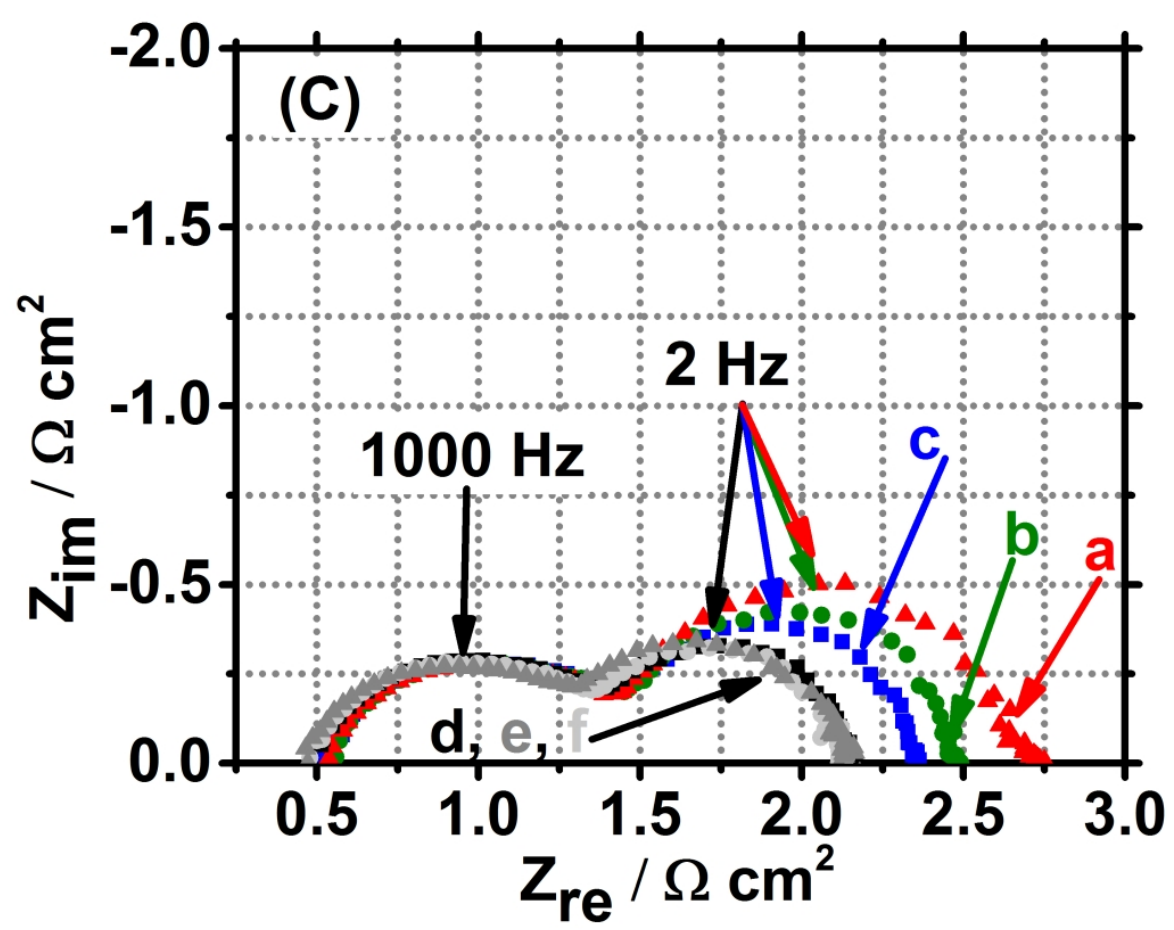

Figure 4. A: Voltage ( $a, b$ and $c)$ and power density versus current density $\left(a^{\prime}, b^{\prime}\right.$ and $\left.c^{\prime}\right)$ characteristics recorded at $10 \mathrm{mV} \mathrm{s}-1$ under dry air $(400 \mathrm{~mL} \mathrm{~min}-1)$ on the air side and wet (3\% $\mathrm{H} 2 \mathrm{O}) \mathrm{H} 2$ (a and $\mathrm{a}^{\prime}: 107$ $\mathrm{mL} \min -1, b$ and $b^{\prime}: 83 \mathrm{~mL} \min -1$, and $c$ and $\left.c^{\prime}: 57 \mathrm{~mL} \mathrm{~min}-1\right)$ on the fuel side, at $850{ }^{\circ} \mathrm{C}$ and $\mathrm{B}$ : Voltage (d, e and $f$ ) and power density versus current density ( $d^{\prime}, e^{\prime}$ and $\left.f^{\prime}\right)$ characteristics recorded at $10 \mathrm{mV} \mathrm{s}-1$ under dry air ( $d$ and $d^{\prime}: 300 \mathrm{~mL}$ min-1, e and $e^{\prime}: 200 \mathrm{~mL}$ min-1, and $f$ and $f^{\prime}: 100 \mathrm{~mL}$ min-1) on the air side and wet $(3 \% \mathrm{H} 2 \mathrm{O}) \mathrm{H} 2\left(157 \mathrm{~mL}\right.$ min-1) on the fuel side, at $850^{\circ} \mathrm{C}$. Corresponding Nyquist (C) and Bode (D) diagrams recorded at $850^{\circ} \mathrm{C}$ at OCV under dry air $(a, b$ and $c: 400 \mathrm{~mL} \min -1$, d: $300 \mathrm{~mL} \mathrm{~min}-1$, e: $200 \mathrm{~mL}$ min-1, f: $100 \mathrm{~mL}$ min-1) on the air side and wet $(3 \% \mathrm{H} 2 \mathrm{O}) \mathrm{H} 2$ (a: $107 \mathrm{~mL} \mathrm{~min}-1, \mathrm{~b}: 83 \mathrm{~mL} \mathrm{~min}-1, \mathrm{c}: 57 \mathrm{~mL}$ $\min -1, d$, e and $\mathrm{f}: 157 \mathrm{~mL} \mathrm{min-1)}$ on the fuel side, at $850^{\circ} \mathrm{C}$. Numbers mentioned above the diagrams of Figure $\mathrm{C}$ are the frequency values.

$163 \times 125 \mathrm{~mm}(500 \times 500 \mathrm{DPI})$ 


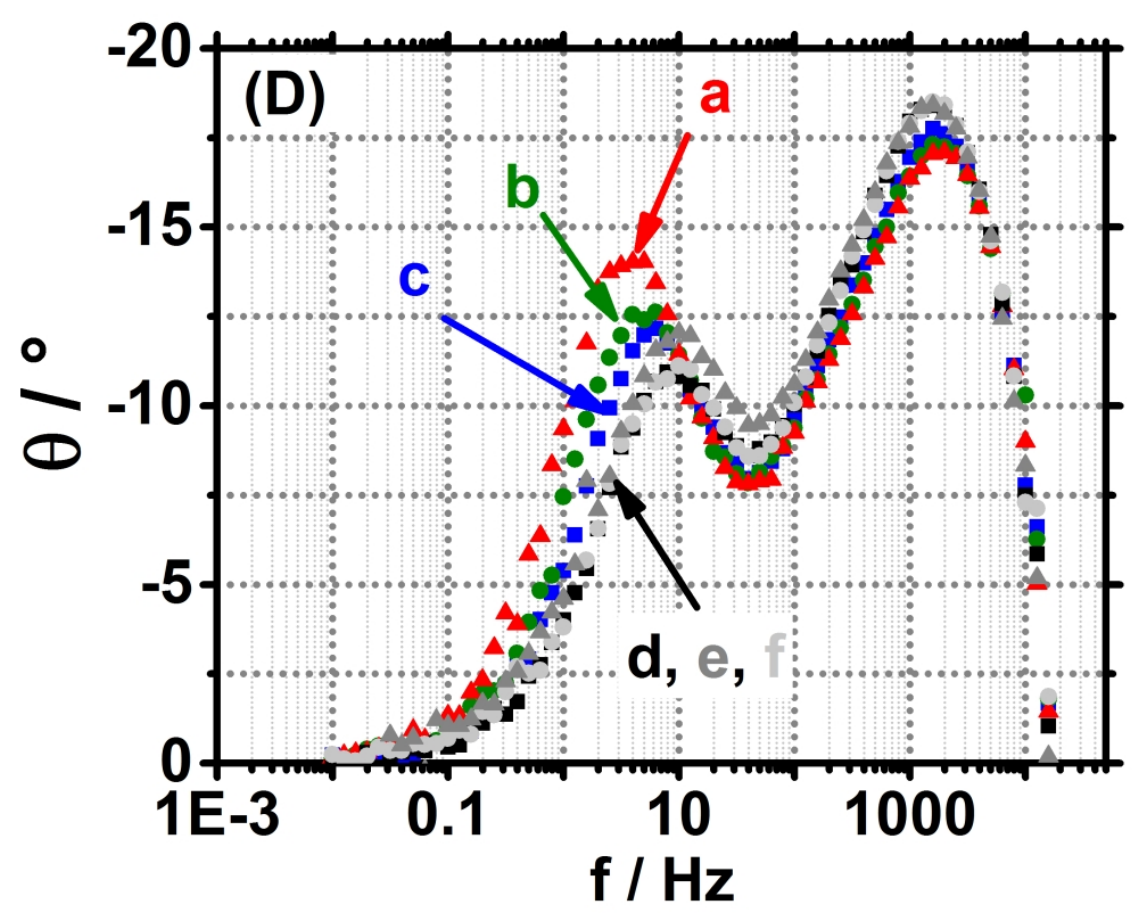

Figure 4. A: Voltage ( $a, b$ and $c)$ and power density versus current density $\left(a^{\prime}, b^{\prime}\right.$ and $\left.c^{\prime}\right)$ characteristics recorded at $10 \mathrm{mV} \mathrm{s}-1$ under dry air (400 mL min-1) on the air side and wet ( $3 \% \mathrm{H} 2 \mathrm{O}) \mathrm{H} 2$ (a and $\mathrm{a}^{\prime}: 107$ $\mathrm{mL} \min -1, b$ and $b^{\prime}: 83 \mathrm{~mL} \min -1$, and $\mathrm{c}$ and $\left.\mathrm{c}^{\prime}: 57 \mathrm{~mL} \mathrm{~min}-1\right)$ on the fuel side, at $850^{\circ} \mathrm{C}$ and $\mathrm{B}$ : Voltage (d, $e$ and f) and power density versus current density ( $d^{\prime}$, $e^{\prime}$ and $\left.f^{\prime}\right)$ characteristics recorded at $10 \mathrm{mV} \mathrm{s}-1$ under dry air (d and d': $300 \mathrm{~mL}$ min-1, e and e': $200 \mathrm{~mL}$ min-1, and $f$ and f': $100 \mathrm{~mL}$ min-1) on the air side and wet $(3 \% \mathrm{H} 2 \mathrm{O}) \mathrm{H} 2\left(157 \mathrm{~mL}\right.$ min-1) on the fuel side, at $850{ }^{\circ} \mathrm{C}$. Corresponding Nyquist (C) and Bode (D) diagrams recorded at $850^{\circ} \mathrm{C}$ at OCV under dry air (a, b and c: $400 \mathrm{~mL} \mathrm{~min}-1, \mathrm{~d}: 300 \mathrm{~mL} \mathrm{~min}-1$, e: $200 \mathrm{~mL}$ min-1, f: $100 \mathrm{~mL}$ min-1) on the air side and wet (3\% H2O) H2 (a: $107 \mathrm{~mL}$ min-1, b: $83 \mathrm{~mL}$ min-1, c: $57 \mathrm{~mL}$ $\mathrm{min}-1, \mathrm{~d}$, e and f: $157 \mathrm{~mL} \mathrm{~min}-1$ ) on the fuel side, at $850^{\circ} \mathrm{C}$. Numbers mentioned above the diagrams of Figure $\mathrm{C}$ are the frequency values.

$163 \times 125 \mathrm{~mm}(500 \times 500$ DPI $)$ 

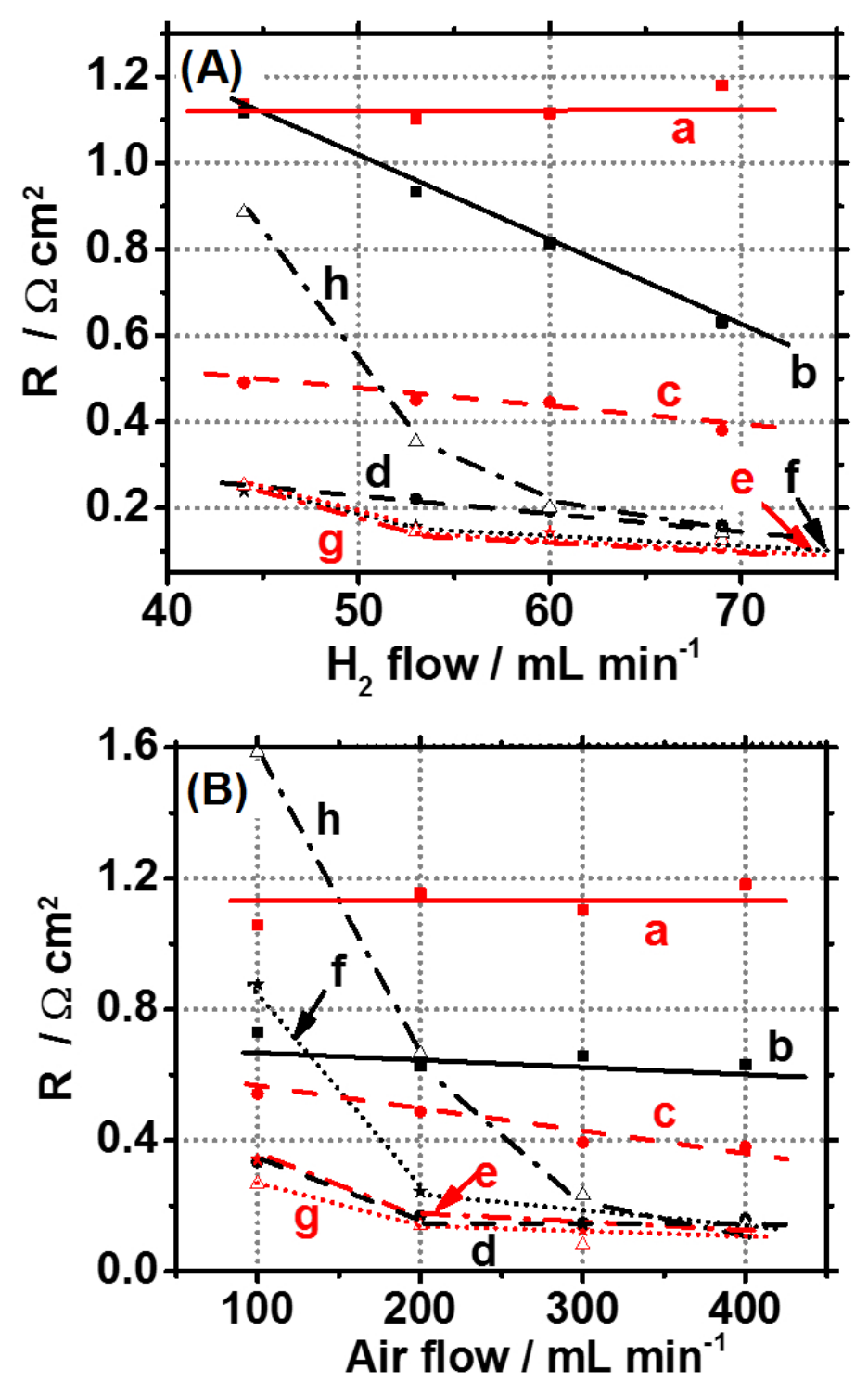

Figure 5 A: Variations of the resistance R2 ( $a, c$, e and $g$ ) and R3 (b, d, f and h) values determined from impedance diagrams recorded at $850{ }^{\circ} \mathrm{C}$ under dry air $(400 \mathrm{~mL}$ min-1) on the air side with the flow rate of wet $(3 \% \mathrm{H} 2 \mathrm{O}) \mathrm{H} 2$ fueling the fuel side at OCV ( $\mathrm{a}$ and $\mathrm{b}$ ), at $0.8 \mathrm{~V}(\mathrm{c}$ and $\mathrm{d}$ ), $0.6 \mathrm{~V}$ (e and $\mathrm{f}$ ) and $0.4 \mathrm{~V}(\mathrm{~g}$ and

h). B: Variations of the resistance R2 ( $a, c$, e and $g$ ) and R3 (b, d, f and h) values determined from impedance diagrams recorded at $850{ }^{\circ} \mathrm{C}$ under wet $(3 \% \mathrm{H} 2 \mathrm{O}) \mathrm{H} 2(157 \mathrm{~mL} \mathrm{~min}-1)$ on the fuel side with the flow rate of dry air fueling the air side at OCV ( $a$ and $b$ ), at $0.8 \mathrm{~V}$ (c and d), $0.6 \mathrm{~V}$ (e and f) and $0.4 \mathrm{~V}(\mathrm{~g}$ and $h$ ).

$33 \times 49 \mathrm{~mm}(600 \times 600 \mathrm{DPI})$ 

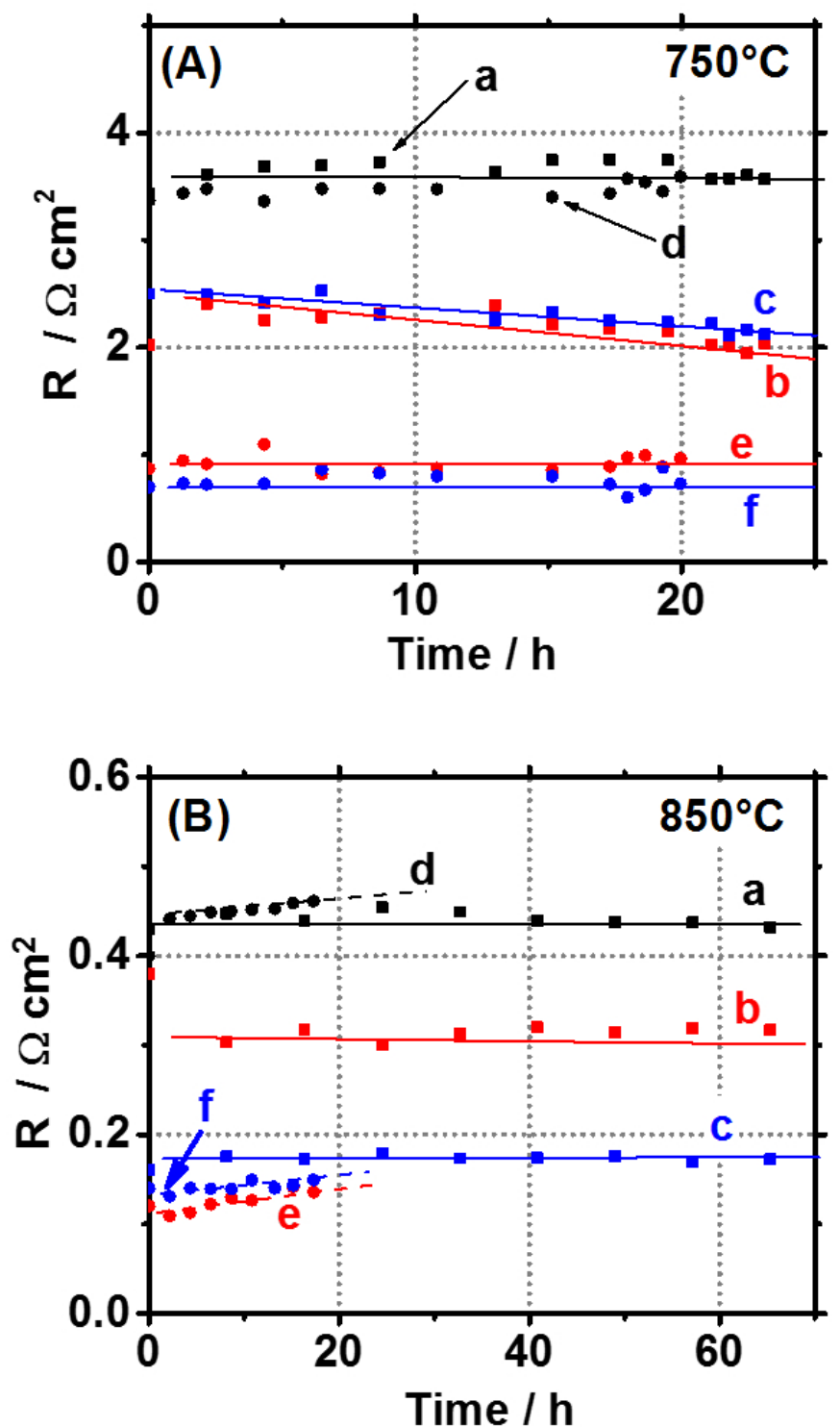

Figure 6. Variations with time of three resistances R1 ( $a$ and d), R2 ( $b$ and e) and R3 ( $c$ and f) values determined from impedance diagrams recorded when the cell is maintained at $0.8 \mathrm{~V}(\mathrm{a}, \mathrm{b}$ and $\mathrm{c})$ or $0.4 \mathrm{~V}(\mathrm{~d}$, e and f) under dry air ( $400 \mathrm{~mL} \mathrm{min-1)}$ on the air side and wet $(3 \% \mathrm{H} 2 \mathrm{O}) \mathrm{H} 2(153 \mathrm{~mL} \mathrm{~min}-1)$ on the air side, at $750^{\circ} \mathrm{C}(\mathrm{A})$ and $850^{\circ} \mathrm{C}(\mathrm{B})$.

$36 \times 56 \mathrm{~mm}(500 \times 500$ DPI) 


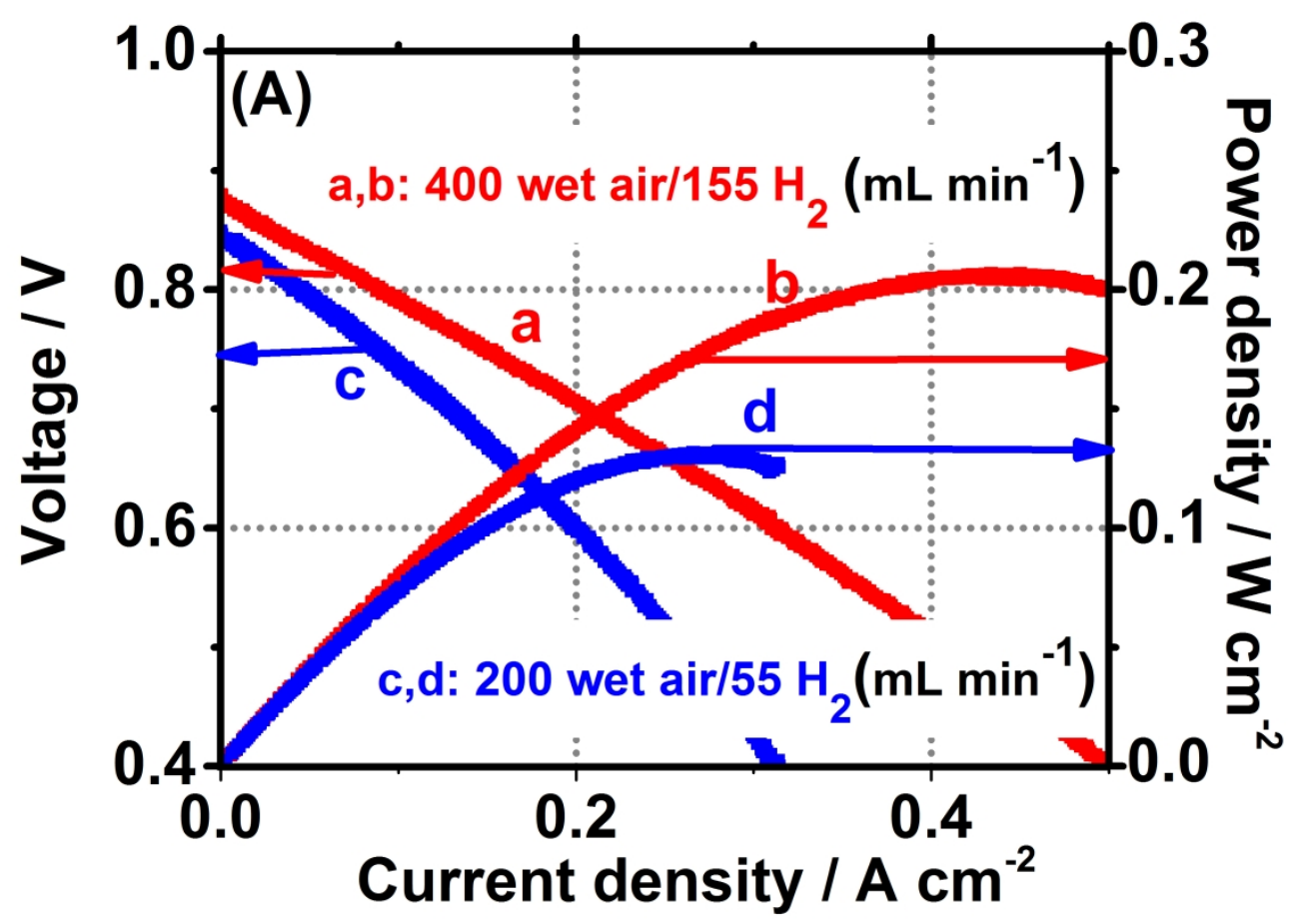

Figure 7. A: Voltage ( $a$ and $c$ ) and power density ( $b$ and $d$ ) versus current density characteristics recorded at $850^{\circ} \mathrm{C}$ and $10 \mathrm{mV} \mathrm{s}-1$ under wet air $(400 \mathrm{~mL} \mathrm{~min}-1)$ on the air side and wet $(3 \% \mathrm{H} 2 \mathrm{O}) \mathrm{H} 2(155 \mathrm{~mL} \mathrm{~min}-1)$ on fuel side ( $a$ and $b$ ) and under wet air ( $200 \mathrm{~mL} \mathrm{min-1)}$ on the air side and wet ( $3 \% \mathrm{H} 2 \mathrm{O}$ ) H2 (55 mL min-

1) on the fuel side (c and d). Nyquist diagrams recorded at $850^{\circ} \mathrm{C}$ and $10 \mathrm{mV} \mathrm{s}-1$ under wet air ( $400 \mathrm{~mL}$ min-1) on the air side and wet $(3 \% \mathrm{H} 2 \mathrm{O}) \mathrm{H} 2(155 \mathrm{~mL} \mathrm{~min}-1)$ on fuel side (B) and under wet air ( $200 \mathrm{~mL}$ min-1) on the air side and wet $(3 \% \mathrm{H} 2 \mathrm{O}) \mathrm{H} 2(55 \mathrm{~mL} \mathrm{~min}-1)$ on the fuel side (C), and at OCV (a), $0.8 \mathrm{~V}$ (b), $0.6 \mathrm{~V}(\mathrm{c})$ and $0.4 \mathrm{~V}(\mathrm{~d})$. Numbers mentioned above the diagram are the frequency values. 


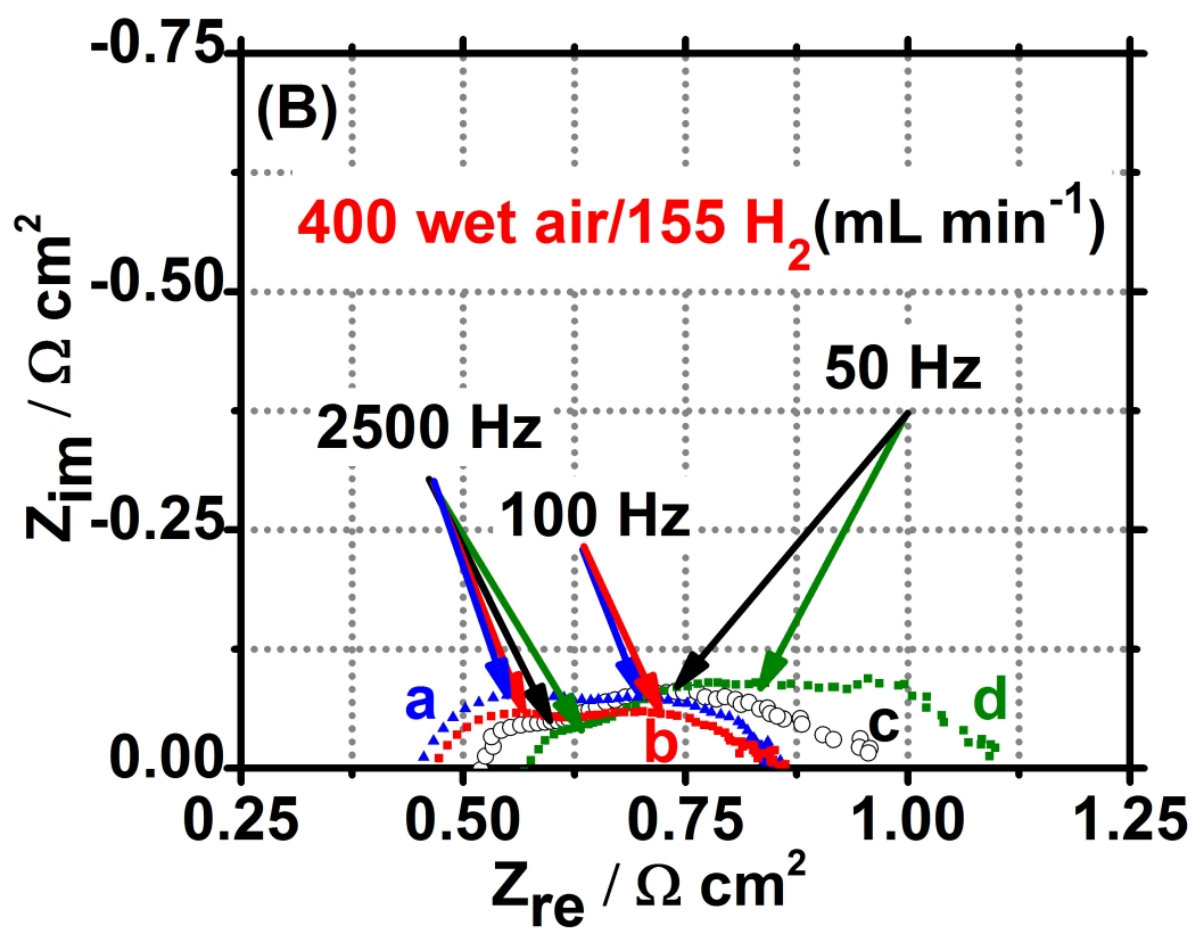

Figure 7. A: Voltage ( $a$ and $c$ ) and power density ( $b$ and d) versus current density characteristics recorded at $850^{\circ} \mathrm{C}$ and $10 \mathrm{mV} \mathrm{s}-1$ under wet air $(400 \mathrm{~mL} \mathrm{~min}-1)$ on the air side and wet $(3 \% \mathrm{H} 2 \mathrm{O}) \mathrm{H} 2(155 \mathrm{~mL} \mathrm{~min}-1)$ on fuel side ( $a$ and $b$ ) and under wet air $(200 \mathrm{~mL}$ min-1) on the air side and wet ( $3 \% \mathrm{H} 2 \mathrm{O}$ ) H2 (55 mL min-

1) on the fuel side (c and d). Nyquist diagrams recorded at $850^{\circ} \mathrm{C}$ and $10 \mathrm{mV} \mathrm{s}-1$ under wet air ( $400 \mathrm{~mL}$ min-1) on the air side and wet $(3 \% \mathrm{H} 2 \mathrm{O}) \mathrm{H} 2(155 \mathrm{~mL} \mathrm{~min}-1)$ on fuel side (B) and under wet air ( $200 \mathrm{~mL}$ min-1) on the air side and wet $(3 \% \mathrm{H} 2 \mathrm{O}) \mathrm{H} 2(55 \mathrm{~mL} \mathrm{~min}-1)$ on the fuel side (C), and at OCV (a), $0.8 \mathrm{~V}$ (b), $0.6 \mathrm{~V}(\mathrm{c})$ and $0.4 \mathrm{~V}(\mathrm{~d})$. Numbers mentioned above the diagram are the frequency values.

$181 \times 138 \mathrm{~mm}(450 \times 450 \mathrm{DPI})$ 


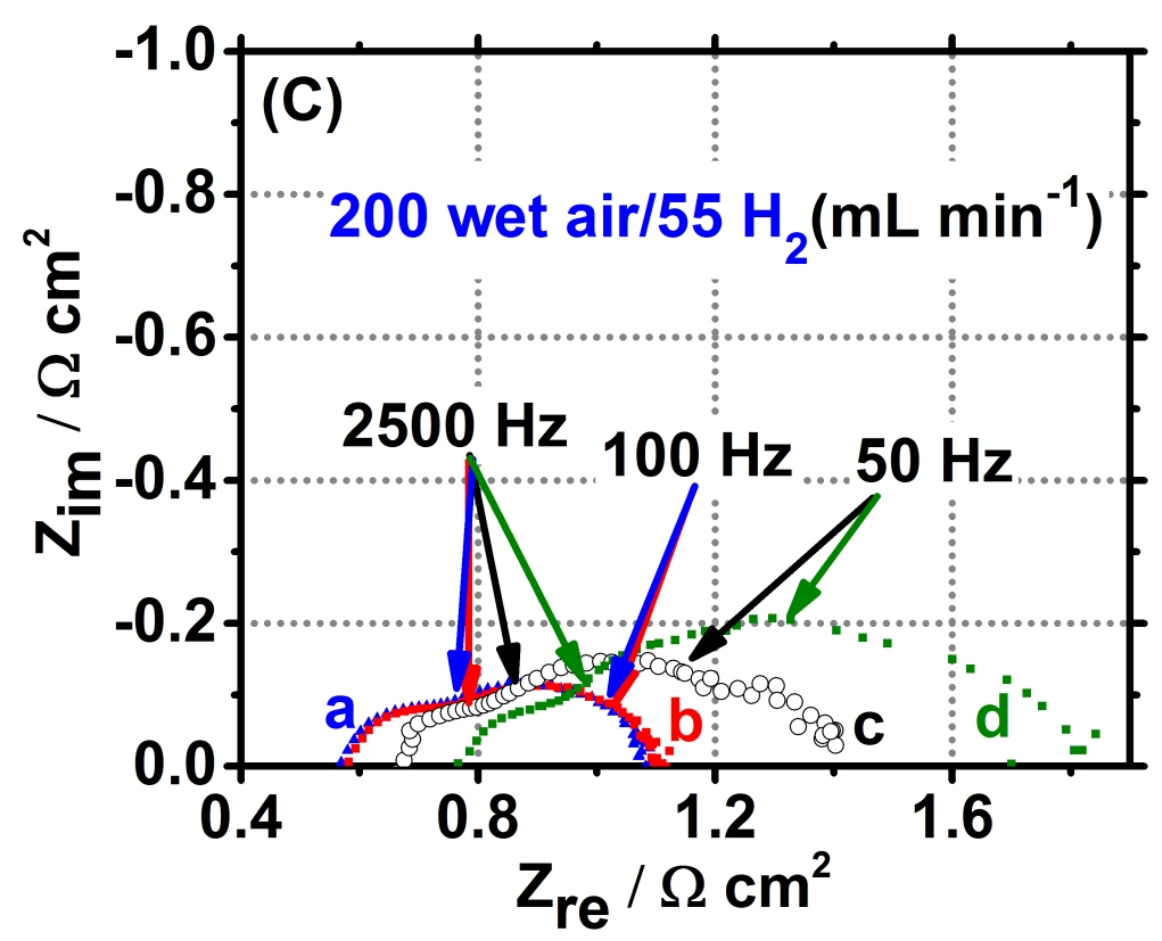

Figure 7. A: Voltage ( $a$ and $c$ ) and power density ( $b$ and $d$ ) versus current density characteristics recorded at $850^{\circ} \mathrm{C}$ and $10 \mathrm{mV} \mathrm{s}-1$ under wet air $(400 \mathrm{~mL} \mathrm{~min}-1)$ on the air side and wet (3\% H2O) H2 (155 mL min-1) on fuel side ( $a$ and $b$ ) and under wet air $(200 \mathrm{~mL}$ min-1) on the air side and wet (3\% H2O) H2 (55 mL min-

1 ) on the fuel side ( $\mathrm{C}$ and d). Nyquist diagrams recorded at $850^{\circ} \mathrm{C}$ and $10 \mathrm{mV} \mathrm{s}-1$ under wet air (400 mL min-1) on the air side and wet $(3 \% \mathrm{H} 2 \mathrm{O}) \mathrm{H} 2(155 \mathrm{~mL} \mathrm{~min}-1)$ on fuel side (B) and under wet air (200 mL min-1) on the air side and wet $(3 \% \mathrm{H} 2 \mathrm{O}) \mathrm{H} 2(55 \mathrm{~mL} \mathrm{~min}-1)$ on the fuel side (C), and at OCV (a), $0.8 \mathrm{~V}(\mathrm{~b})$, $0.6 \mathrm{~V}(\mathrm{c})$ and $0.4 \mathrm{~V}(\mathrm{~d})$. Numbers mentioned above the diagram are the frequency values.

$181 \times 138 \mathrm{~mm}(450 \times 450 \mathrm{DPI})$ 


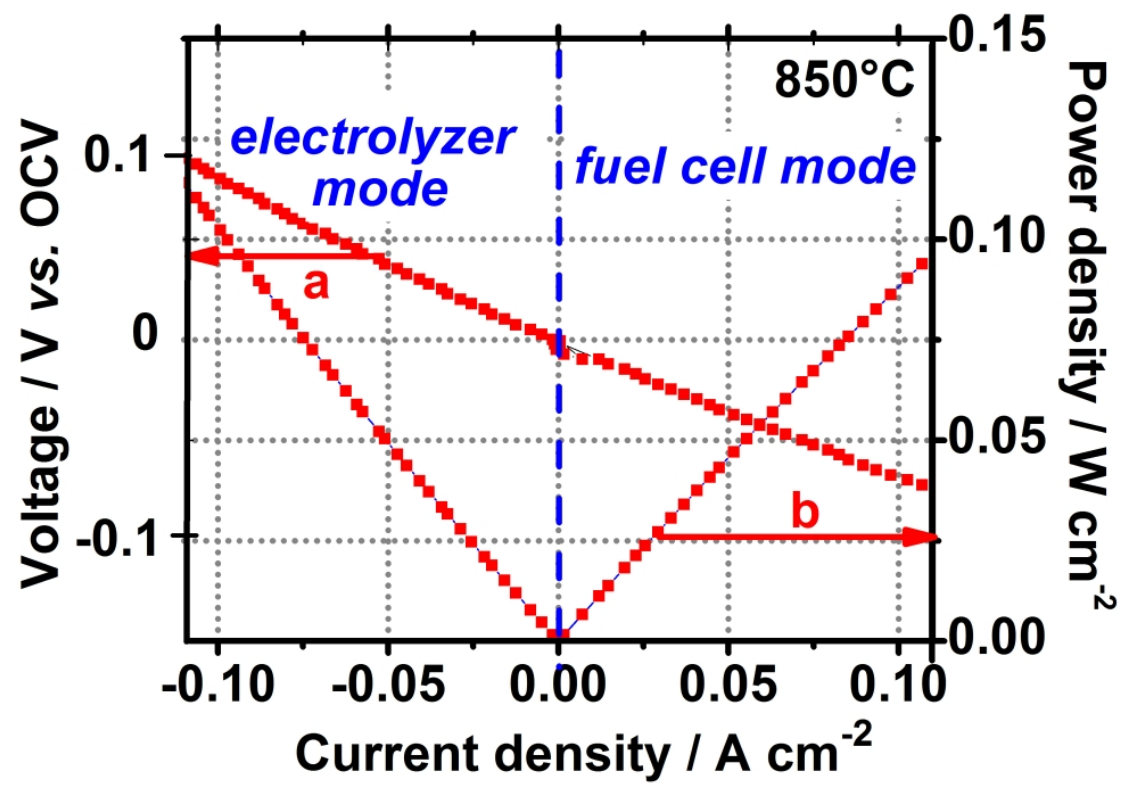

Figure 8. Voltage (a) and power density (b) versus current density characteristics recorded at $850^{\circ} \mathrm{C}$ and 10 $\mathrm{mV} \mathrm{s}-1$ under a $250 \mathrm{~mL}$ min-1 flow of dry $(3 \% \mathrm{H} 2 \mathrm{O}) 62 \% \mathrm{H} 2-38 \%$ Ar mixture (i.e. corresponding to a $\mathrm{H} 2$ flow of $155 \mathrm{~mL} \mathrm{min-1)}$ on the fuel side and dry air $(400 \mathrm{~mL} \mathrm{~min}-1)$ on the air side, between $-0.12 \mathrm{~A} \mathrm{~cm}-2$ and $+0.12 \mathrm{~A} \mathrm{~cm}-2$.

$194 \times 140 \mathrm{~mm}(500 \times 500 \mathrm{DPI})$ 